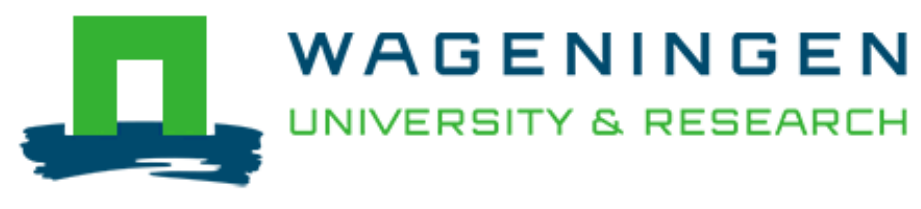

\author{
Technical, environmental and cost-benefit assessment of manure \\ management chain: A case study of large scale dairy farming \\ Sefeedpari, P., Vellinga, T., Rafiee, S., Sharifi, M., Shine, P., \& Pishgar- \\ Komleh, S. H.
}

This is a "Post-Print" accepted manuscript, which has been Published in "Journal of Cleaner Production"

This version is distributed under a non-commercial no derivatives Creative Commons (C) $(1) \Theta$ reproduction in any medium, provided the original work is properly cited and not used for commercial purposes. Further, the restriction applies that if you remix, transform, or build upon the material, you may not distribute the modified material.

Please cite this publication as follows:

Sefeedpari, P., Vellinga, T., Rafiee, S., Sharifi, M., Shine, P., \& Pishgar-Komleh, S. H. (2019). Technical, environmental and cost-benefit assessment of manure management chain: A case study of large scale dairy farming. Journal of Cleaner Production, 233, 857-868. https://doi.org/10.1016/j.jclepro.2019.06.146

You can download the published version at:

https://doi.org/10.1016/j.jclepro.2019.06.146 


\title{
Technical, environmental and cost-benefit assessment of manure management chain: a case study of large scale dairy farming
}

\author{
Paria Sefeedpari ${ }^{1,2,3^{*}}$, Theun Vellinga ${ }^{2}$, Shahin Rafiee ${ }^{1 *}$, Mohammad Sharifi $^{1}$, Philip Shine ${ }^{4}$, Seyyed \\ Hassan Pishgar-Komleh ${ }^{5}$
}

${ }^{1}$ Department of Agricultural Machinery, Faculty of Agricultural Engineering and Technology, University of Tehran, Karaj, P.O. Box 4111, Iran.

${ }^{2}$ Wageningen Livestock Research, Wageningen University and Research, PO Box 338, 6700 AH, Wageningen, The Netherlands.

${ }^{3}$ Institute of Soil Science and Plant Cultivation-State Research Institute, P.O. Box 24100 Puławy, Poland

${ }^{4}$ Department of Process, Energy and Transport Engineering, Cork Institute of Technology, Cork, Ireland

${ }^{5}$ Department of Economics, Faculty of Economics and Management, Czech University of Life Sciences Prague, Kamýcká 129, 16500 Prague, Suchdol, Czech Republic

*Corresponding author email: pariasefeedpari@ut.ac.ir

Postal address: Department of Agricultural Machinery Engineering, Faculty of Agricultural Engineering and Technology, University of Tehran, P.O. Box 4111, Karaj 31587-77871, Iran

Tel: (+98) 2632801011

Fax: (+98) 2632808138

9 Abstract

Improper management of livestock manure has resulted in loss of nutrients and organic matter available in manure in addition to negative environmental impacts. This study developed and compared eight manure management scenarios across their entire life cycles, rom excretion to transport to land, considering technical, environmental and economic aspects. The scenarios based on combinations of collection, sand separation, solid/liquid (S/L) separation, anaerobic digestion (AD), composting, and storage were compared. Mass balances, costs and benefits and greenhouse emissions were evaluated. The model framework was tested and validated for a large-scale dairy farm with 9,000 heads of cattle and daily 
is manure production of approximately $505 \mathrm{t}$ in Iran. The study indicated that sand separation rq and S/L separation did not contribute to a change in manure nutrients or emissions but r. reduced sand, maintenance cost, and transport requirements. AD followed by separation r) achieved the highest emission reduction $\left(27.7 \mathrm{~kg} \mathrm{CO}_{2 \mathrm{eq}} \mathrm{t}^{-1}\right)$ due to the avoided emissions from rr replacing fossil fuels by renewable energy. Composting method had the lowest costs; r however it resulted in a low nutrient recovery efficiency and high nitrous oxide emission. The $r \varepsilon$ assessment revealed that $\mathrm{AD}$ is a promising management option yielding a high potential ro greenhouse gas savings, nutrients recovery and nitrogen availability in fertilizer for plants. In r 1 spite of the high investment costs of $\mathrm{AD}$, it could be a profitable strategy due to the high rv subsidies paid to renewable energy projects in Iran. In conclusion, this study showed that the rs choice of manure treatment method has a strong influence on nutrients, profitability and rq greenhouse gas balances by performing sensitivity analysis. The results of this study and the \&. application of this model further indicate the need to consider various significant impacts, \&) farm specifications and local conditions to decide the best manure management options.

\&r Keywords: Manure management; Environmental analysis; Cost-benefit analysis; Anaerobic \&r digestion; Dairy. 


\section{Introduction}

$\varepsilon V$

Manure is an output of livestock production systems that is being increasingly sought after as a valuable resource to supply nutrients to soil, as a replacement to costly synthetic fertilisers (Audsley and Wilkinson, 2014). Manure treatment strategies such as manure to energy practices can help return organic matter to the soil, while concentrating nutrients for easier and less costly uses. These benefits offer opportunities for extending the concept of nutrients circularity in agriculture and livestock production in particular, shifting perception from manure as a problem to manure as a resource.

Manure is one of the key agricultural greenhouse gas (GHG) sources (second important GHG source after enteric fermentation) and accounts for about $10 \%$ of on-farm emissions (O’Mara, 2011). Although the livestock industry is not considered a major producer of $\mathrm{CO}_{2}$, it is considered as the source of other greenhouse gases, such as methane $\left(\mathrm{CH}_{4}\right)$ and nitrous oxide $\left(\mathrm{N}_{2} \mathrm{O}\right)$ (Chianese et al., 2009). Processing of manure would result in the release of emissions to air, soil and water (Pratt et al., 2015). The most suitable manure management strategy depends on a combination of factors including economic feasibility, governmental policies, financial incentives, and social acceptance (Montalvo, 2008). Selecting the most efficient manure management strategy must ensure the profitability of investment (Burney et al., 1980). Minimizing the total cost of a chain is desired while the constraints are fulfilled (Gharaei et al., 2017). As the main aim of manure management is to adapt the business goals and strategies to the competitive market, it is essential to conduct investments within a reliable supply chain (Hoseini Shekarabi et al., 2018). In a real world scenario, such chains can be modelled and optimized in order to minimize the cost of the chain (Gharaei et al., 2017). 
$\vee \quad \quad \mathrm{N}, \mathrm{P}$ and $\mathrm{K}$ content, organic matter and volume of the initial stream is defined as excreted and collected on the dairy farm. These will be affected by manure processing, which in turn will define the quality of the end products (e.g. fertilizer).

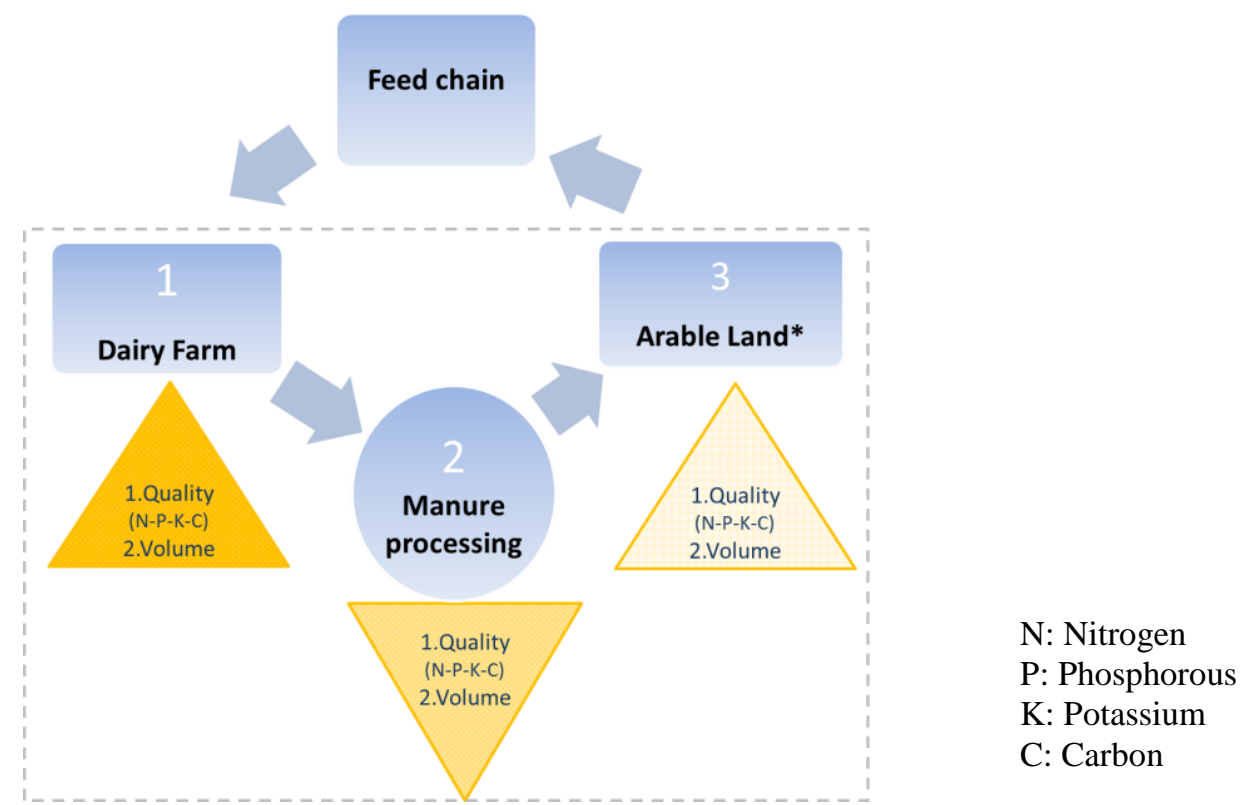

Fig. 1. The simplified nutrient cycling system in livestock production. The dotted line depicts the system boundary of the chain under study

One critical issue with intensification of dairy farming systems in Iran, i.e. high stocking densities of dairy farms, is due to the alienation between increasing the farm size and the environmental and economic challenges. This problem has been driven by a number of management adjustments, such as improved manure management systems. This improvement has not been addressed yet in academic research projects in Iran and as the observations showed, all these improvements are carried out without being technically feasible, economically and environmentally justified. These problems are due to lack of adequate manure management policies. In most cases, manure is left on land, sun-dried and possibly sold for applying on arable farms. On the other hand, manure has a farm gate value in Iran, i.e. farmers can receive a payment for selling manure as an organic fertilizer or bioenergy 
NT resource. This has caused manure processing to increasingly becoming attractive to dairy $\Lambda \leqslant$ farmers.

Modelling approaches for nutrient flows and mass balance (MB) of materials in and out of MMC (especially $\mathrm{N}$ and $\mathrm{P}$ ) have been studied at the global, regional, and national levels all over the world. Petersen et al. (2007) stated that a whole farm perspective taking the on-farm interactions into account is needed. A regional based study on manure management systems in the European Union (EU-27) has been assessed by Oenema et al. (2007). Chadwick et al. (2015) reviewed manure management practices both at the national and regional scale. There are some models, which have focused on the single emissions of livestock production such as ammonia $\left(\mathrm{NH}_{3}\right)$ (Reidy et al., 2008), and $\mathrm{CH}_{4}$ and $\mathrm{N}_{2} \mathrm{O}$ (Sommer et al., 2004). Sommer et al. (2004) developed a dynamic model to calculate $\mathrm{CH}_{4}$ and $\mathrm{N}_{2} \mathrm{O}$ emissions through a whole chain of manure management from collection to application.

A wide range of studies have been conducted to analyse the environmental and/or economic benefits of a single manure treatment method. These include: De Vries et al. (2012) studied environmental consequences of anaerobic digestion (AD) using life cycle assessment (LCA), Mezzullo et al. (2013) studied LCA of a small-scale AD, ten Hoeve et al. (2014) conducted a LCA of mechanical separation, and Torquati et al. (2014) assessed the economic viability of biogas production from manure. Similar assessments of a single manure treatment method have been conducted by Junior et al. (2015) on GHG emissions from AD of beef manure, Blumenstein et al. (2018) on economic profitability of AD, Yazan et al. (2018) on economic sustainability of manure based biogas supply chains, and Rennie et al. (2018) on modelling assessment of liquid manure storage. Other studies have focused on a combination of manure treatment practices. Aguirre-Villegas et al. (2014) assessed four different manureprocessing pathways for their environmental impacts on different sustainability indicators. These pathways included solid/liquid (S/L) separation, AD, AD plus S/L separation and a 
1.1 base-case pathway of no manure treatment and direct land application of manure. Integrated 1.9 manure management methods were evaluated by Aguirre-Villegas and Larson (2017) using

11. LCA tools. Selecting among different manure management strategies were studied in Polish 111 pig farms. This study proposed that the best manure treatment methods involved applying IIr half of the pig manure on arable farms, processing of the other half by filtration, while IIr excluding the storage of manure in lagoons (Makara and Kowalski, 2018).

$11 \leqslant$ A number of studies have applied supply chain modelling and optimization. Gharaei and 110 Pasandideh (2017) modelled the costs in an integrated supply chain. Based on their findings, 117 the optimization of an integrated supply chain in co-operation with the supply chain IIV managers can prove beneficial and applicable for them to minimize the total inventory cost of 111 the chain.

119 Although many researchers have focused on manure management, no studies in literature Ir. have considered assessing manure management across the entire chain from manure ir) excretion to land application, while carrying out a farm-level technical, environmental and irr economic analysis. No research has been conducted in Iran related to manure management Irr and different technologies from a whole chain perspective. To illustrate the originality of the I $\{$ s current study compared to the previous works in the literature review are presented in Table iro $S 1$

ir As discussed above, there is lack of comprehensive knowledge and information among irv dairy farmers and stakeholders related to manure management strategies in Iran. On this IrA basis, this paper aims to demonstrate the current situation of manure management in Iran, irq while analysing the environmental and economic impacts of eight potential manure 1r. management strategies. Potential and quality assessment of manure production was carried ir) out at farm-level and based on the current real situation on the farms, feed ration and herd irr characteristics including body weight, energy requirements and milk quality. This study aims 
to fill the gap between understanding the effects of selecting different manure management strategies and the up-take of this knowledge by farmers during their decision making process. This research will address a key question in manure management: what are the economic and environmental impacts of different manure management methods for a specific farm? To answer this question, this study is elaborated at four different levels: (i) developing a spreadsheet framework to calculate the potential of manure production and its quality; (ii) analysing different manure treatment strategies based on three dimensions (technical, environmental and economic); (iii) tracking and accounting the nutrients flows, emissions and losses within the MMC; and (iv) testing and validating the framework for the case under study in Iran under different eight alternative scenarios.

The authors designed and tested a framework for conducting all calculations of the whole manure management chain from technical aspects through assessing different scenarios, environmental impact through assessing GHG emissions and economic impact through cost and benefit analysis. Integrating these three aspects and studying different manure management systems in large-scale dairy farming in Iran are other novelties of this paper. Estimating the potential of manure production and its characteristics based on herd structure, cattle characteristics in a farm and dietary highlight the novelty of this work (Table S1).

The paper is structured as follows: firstly, an overview of the framework is given, before the manure treatment processes are described. This is then followed by a description of the economic methods and the description of different scenarios. Results of applying the model for assessing the environmental and economic impacts of each scenario are then presented and discussed before the paper ends with concluding remarks.

\section{Material and methods}

\subsection{Model description}


lov In this study, the Technical, Environmental, and Cost-Benefit Analysis of Manure 101 Management Chain (TECBA-MMC) model framework (Fig. 2) was developed based on a 109 process-based analysis and a MB approach. The TECBA-MMC model framework calculates: 17. (i) N, P, K and C flows, volatile solids (VS) and degradation rates, losses through emissions 17) to air, soil and water during collection, transport, S/L separation, long-term storage and final ir transport to arable land, (ii) the quality of the final product(s) and (iii) environmental impacts, ir costs and benefits along the whole MMC. The model framework is represented in a modular 17 way. Within this framework, the quality of the ingoing manure can be calculated or can be 170 defined by the user. The technologies and methods of manure treatment can be selected by 174 the user of model. For example, one can go from Transport 1 (as shown in Fig. 2) to I7v composting directly. The effluent of one step is the influent to the next step, whereby within 17 each step, a MB is calculated, keeping track of all changes in N, P, K, C and total mass due to 179 conversions, losses and emissions. Manure quality may be calculated after each step by iv. dividing nutrient amounts by the total mass. The detailed calculation methodology and (v) parameters used are presented in the Supplementary Information (SI). 


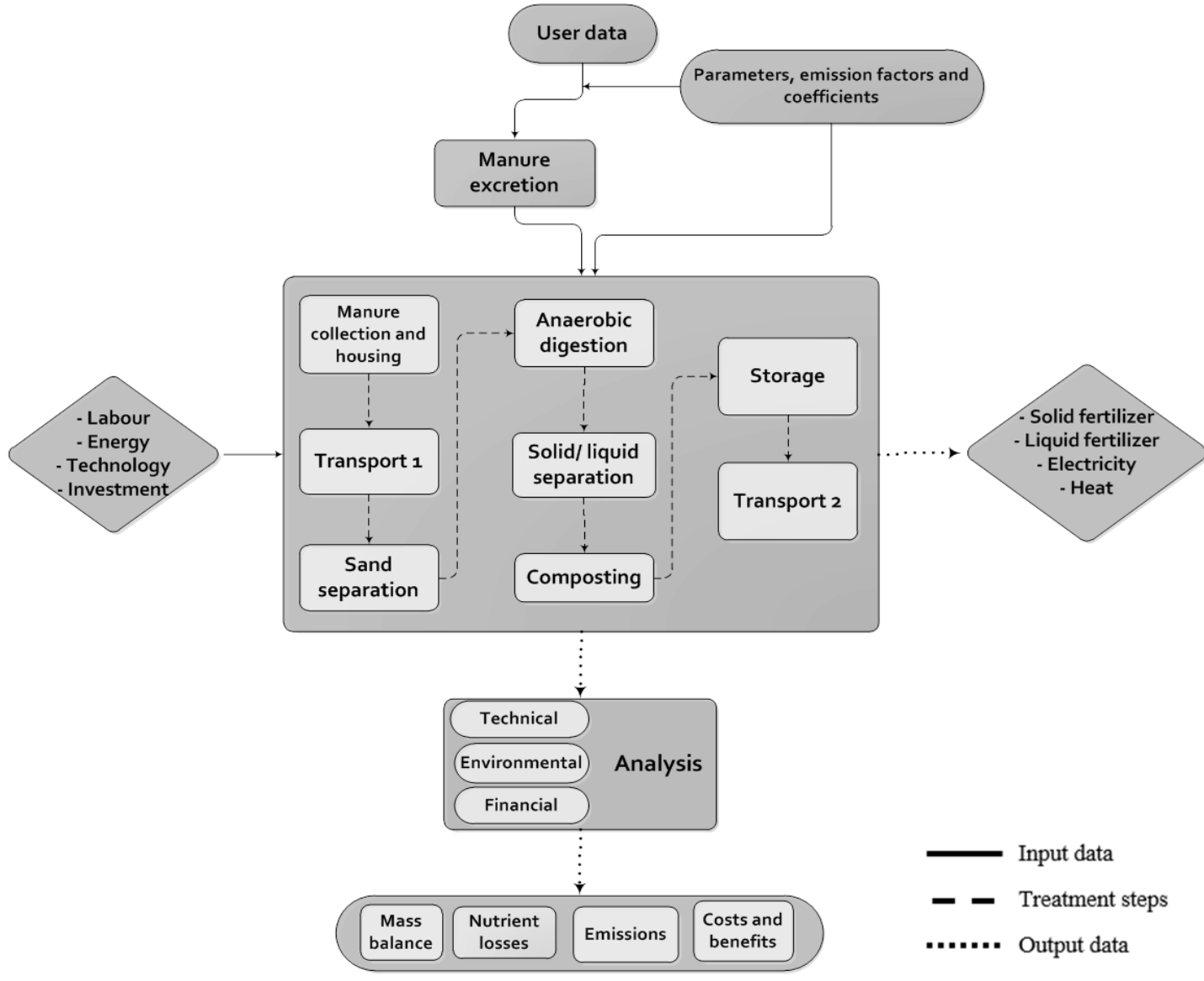

Fig. 2. Modelling framework for the TECBA-MMC model

\subsection{Manure excretion}

Accurate estimation of the quality and amount of inflow is essential for an accurate design of manure processing and treatment, as well as the quality of the final product. The developed framework allows manure production to be calculated on the basis of animal nutrition for cattle farms. A general method of estimating nutrient excretion is indicated as Eq. (1):

$$
\text { Nutrient Excretion }=\text { Nutrient Intake }- \text { Nutrient Retention }
$$

The nutritional calculations of feed compositions were based on the method used in IPCC (2006), NRC (2001) and the GLEAM model (MacLeod et al., 2018). The equations and detailed data on herd composition and characteristics are listed in the SI (Eqs. (S1-S8) and Tables S2 and S3). The excretion of nutrients via dung and urine were calculated from the amount of nutrients available in the feed intake minus the nutrients retention in body tissue and nutrients export through milk or beef (Nennich et al., 2005) (Eqs. (S9 and S10) and Table 
S4). Measured manure characteristics can also be fed to the model as user defined data. Due to the variation of bedding material from farm to farm (IPCC, 2006), the effect of bedding materials quality on the characteristic of manure has been excluded. More information on nutrients retention coefficients and characteristics is presented in the SI file.

VS of manure are the organic material in livestock manure and consist of both biodegradable and non-degradable fractions (Sommer et al., 2004). The VS content of manure was estimated based on diet, as VS equals the fraction of undigested feed excreted as feces and can be mixed with urine, as indicated in Eq. (S11). VS is formulated by IPCC (2006) (Tier 2) based on the feed intake and digestibility. The degradable and non-degradable volatile solids (VS $\mathrm{V}_{\mathrm{d}}$ and $\mathrm{VS}_{\mathrm{nd}}$ ) were calculated using the Eqs. (S12 and S13). To calculate the total solids (TS) on the basis of volatile solids content $\left(\mathrm{VS}_{\mathrm{tot}}\right)$, conversion coefficients were utilised on the basis of the animal category (Rotz et al., 2016) (Table S5).

Nitrogen in excreta exists in different forms. Fecal $\mathrm{N}$ was assumed to be organic $\mathrm{N}$ (the indigestible fraction of crude protein in feed), and urinary $\mathrm{N}$ (ammoniacal $\mathrm{N}$ ) was considered to be urea (Eqs. (S14 and S15)) (Reijs, 2007). In Vonk et al. (2016), the total ammoniacal nitrogen (TAN) excretion was defined as the sum of excreted urine $\mathrm{N}$ and a fraction of net mineralized $\mathrm{N}$ in feces. This implies that the amount of $\mathrm{N}$-org (organic $\mathrm{N}$ ) is lower than the amount of $\mathrm{N}$ in dung (Eqs. (S16 and S17)).

\subsection{Description of manure treatment methods}

The six manure processes considered in the model framework were: collection and housing, mechanical sand separation, $\mathrm{AD}$, mechanical $\mathrm{S} / \mathrm{L}$ separation, composting, storage and manure hauling. Detailed descriptions of these processes are as follows:

\subsubsection{Collection and housing}

In this model, the user may choose the type of bedding based on the type of housing system. The amount of bedding for each type can be a constant parameter or defined by the 
r.^ user. Collection methods, e.g. blade and loader, scraper, vacuum machine, capacity, power

r.q requirement, collection frequencies, manure temperature in housing and initial costs of

r. collection equipment were inputs to the model. Based on this information, the parameters for

Y) bedding volume (Table S6), the total bedding volume, total fuel consumption, carbon dioxide

rir $\left(\mathrm{CO}_{2}\right)$ emission from diesel use and costs of manure collection were calculated as formulated

rir in Eq. (S18).

r $\leqslant$ Ammonia $\left(\mathrm{NH}_{3}\right)$ emissions in housing were estimated on a TAN excretion basis. This

rio method assumed a linear relation between TAN contents and $\mathrm{NH}_{3}$ emission (Eq. (S19)).

Y 17 Nitrous oxide $\left(\mathrm{N}_{2} \mathrm{O}\right)$ emissions from animal management processes were calculated based on

YIV Vonk et al. (2016). Detailed information related to $\mathrm{N}$ emissions is provided in the SI (Eqs.

rı (S20-S23) and Table S7). It should be noted here that $\mathrm{CO}_{2}$ emissions from livestock were not

r19 estimated since annual net $\mathrm{CO}_{2}$ emissions were assumed to be zero; i.e. the $\mathrm{CO}_{2}$

r. photosynthesized by plants is returned to the atmosphere as respired $\mathrm{CO}_{2} \cdot \mathrm{CH}_{4}$ emissions in

rr) housing were calculated considering the type of housing system (free stall and loose housing

rr system) and the ambient temperature as presented in Eqs. (S24-S26). P and K losses were

rr ignored during the collection and hauling process. Particulate matter $\left(\mathrm{PM}_{2.5}\right.$ and $\left.\mathrm{PM}_{10}\right)$

rrs emissions particularly from animal housing systems were calculated for different animal

rro categories (Eq. (S27) and Table S8).

r r 2.3.2. Mechanical sand separation

rrv In this study, a mechanical separation technique consuming water and electricity was rrs included. To facilitate sand sedimentation, the recycled water returned to the cycle in a rrq dilution rate of 1:1 (one-part water to one-part sand-laden manure). Separated sand, water, rr. and manure effluent were the outputs of this process. The production of sand was not rr, included in the analysis. The sand collected along with manure was quantified as it affects the rm stream down to the next process. No biotic emissions were assumed for sand, and its 
rrr contribution to the nutrient flows was zero. The GHG emissions $\left(\mathrm{CO}_{2}, \mathrm{CH}_{4}\right.$ and $\left.\mathrm{N}_{2} \mathrm{O}\right)$ from

r

rro $\quad \mathrm{kg} \mathrm{CO}_{2 \text {-eq }}$ per $\mathrm{kWh}$ including $15 \%$ losses in grid (Ecoinvent3.3, 2016) (Table S9).

r 2.3.3. Anaerobic digestion $(A D)$

rrv In this model, the AD pathway was a continuous mesophilic processAll information about AD process are provided in Table S10. The source of GHG emissions were fossil fuels used to generate multiple energy streams in the $\mathrm{CHP}$ plant, combustion of $\mathrm{CH}_{4}$, and the gas

rs. leakage from the digester walls. The GHG emissions from the CHP were not considered in the MB analysis since it is up taken via photosynthesis (Whiting and Azapagic, 2014). The potential for energy production was calculated based on the energy content (lower heating value) of produced $\mathrm{CH}_{4}$ minus the $\mathrm{CH}_{4}$ leakage (Eq. (S28)). The electricity production was limited by either the capacity of the generator, the operating time or the amount of available biogas (Eq. (S29)). The heat requirement to maintain the digester in its desired mesophilic operating temperature was calculated using Eqs. (S30 and S31). The VS amount in the effluent was calculated using the Eqs. (S32 and S33). During AD, organic matter converts to biogas $\left(\mathrm{CH}_{4}\right.$ and $\mathrm{CO}_{2}$ gasses). Considering carbon conversion, the $\mathrm{C}$ content of digestate was calculated. This calculation was used for estimating the changes in $\mathrm{VS}_{\mathrm{d}}$. With respect to the recommended dry matter of influent to $\mathrm{AD}$ process, water may be required for diluting manure (Eqs. (S34 and S35)) (Jørgensen, 2009).

\subsubsection{Mechanical solid/liquid separation}

Mass, nutrient and dry matter balances were carried out through applying and extending the model developed by Melse and de Buisonje (2015) for screw press separation. This framework calculated the distribution of minerals and organic matter between different fractions using the certain characteristics such as nutrient contents in $\mathrm{kg} \mathrm{t}^{-1}$ of the effluent, separation efficiency (\%), DM content $\left(\mathrm{kg} \mathrm{t}^{-1}\right)$ of the solid fraction produced and manure 
ros volume to the separator $\left(\mathrm{m}^{3} \mathrm{~d}^{-1}\right)$. GHG emissions due to the separation process were only due

ro9 to the electricity use of the separation equipment.

หฯ. 2.3.5. Composting

หr In this stage, different types of composting equipment can be selected, relevant to the type rre of composting in vessel, static pile, intensive windrow and passive windrow, each with r specific labour and fuel for machinery requirements. During composting, organic matter rı transformation takes place, whereby $\mathrm{NH}_{3}$ may be emitted due to acidification, and GHG rro emissions $\left(\mathrm{CH}_{4}, \mathrm{NH}_{3}, \mathrm{~N}_{2} \mathrm{O}\right)$ are released (Table S12). The losses of $\mathrm{N}, \mathrm{P}, \mathrm{K}$ and $\mathrm{C}$ during rฯ composting will affect the agronomic value of final product as a soil amendment. In Table riv $\mathrm{S} 13$, the $\mathrm{CH}_{4}$ conversion factors during composting are listed. The GHG emissions in this $\uparrow \uparrow$ treatment may be attributed to the diesel use. $\mathrm{CH}_{4}$ emission during composting is related to rr9 the method of composting and temperature (IPCC, 2006).

rv. 2.3.6. Storage

The final product of the manure management system is stored prior to land application. Storage types may be categorized into lagoon, pit (with or without cover) and heap (with or without cover) based on the type of the manure (solid, liquid and slurry) (Tittonell et al., 2010). Manure temperature (Monteny et al., 2001) and the storage duration (Chianese et al., 2009) greatly affect the amount of $\mathrm{CH}_{4}$ produced. The effect of wind velocity and technical factors such as the $\mathrm{C}: \mathrm{N}$ ratio and $\mathrm{pH}$ on the rate of losses in open storage was ignored in this model. The model was run for a seasonal temperature dependency of $\mathrm{CH}_{4}$ emission due to the fact that a quadratic relationship was found between the temperature and $\mathrm{CH}_{4}$ emission factors (EFs) obtained from (IPCC, 2006) (Fig. S1). Coefficients for losses as a percentage of initial influent entering storage and the $\mathrm{EFs}$ of $\mathrm{NH}_{3}$ and $\mathrm{N}_{2} \mathrm{O}$ losses are presented in Tables S14 and S15. 
$r .$.

$r \cdot 1$

$r \cdot r$

\subsubsection{Manure hauling}

The most common method of transporting solid manure was assumed to be by truck. The fuel use for transport by truck and nurse tank was estimated based on the distance and truck specific fuel consumption. These data were obtained from farmers and hauling agencies (truck operators). For road transport of solid manure, the hauling distance determines GHG emissions and the cost of transport (Araji and Stodick, 1990). It is worth mentioning that in this study, the liquid fraction was assumed to stay at the farm for nearby land applications, thus no transport of liquid manure was considered. All the parameters and coefficients used in different manure treatment processes are presented in Table S16.

\subsection{Manure Nutrients Recovery Efficiency}

To compare the nutrients recovery efficiency of different manure management strategies, the manure nutrient recovery efficiency (MNRE) index was introduced. MNRE is the fraction of nutrients in the final product divided by the nutrients in the initial product (Eq. (S36)).

\subsection{Cost- benefit analysis}

For the cost-benefit analysis, all costs of activities (including investment and production costs) were required. These included data related to the total investment costs (TIC) (cost of land (or its opportunity cost), equipment and machinery, site preparation, civil works and preproduction costs), and total production costs (TPC) (energy, labour, maintenance depreciation, insurance and contingency costs). Total revenues (TR) were calculated by multiplying the amount of final products by the prices and correspondingly the gross profit was gained $(\mathrm{GP}=\mathrm{TR}-\mathrm{TPC})$. The required data and the price of other by-products like electricity were collected from different sources such as farmers, manure processors, transport agencies and statistics. The emissions due to sand mining and transport by the buyer were not incorporated in this study. Avoided costs of sand recovery, buying sand and lower maintenance were included in the calculations. To assess the feasibility of future managerial 
$r \cdot \vee$ decisions, profitability indicators including net present value (NPV), internal rate of return

$r \cdot \wedge$ (IRR), benefit to cost ratio (BCR), payback period (PBP) and profitability index (PI) were

r.q evaluated (Eqs. (S37-S42)). More constant values and economic coefficients are listed in

щ. Table S17.

आ1) 2.6. Scenarios description

rir To test the model, eight scenarios were investigated and assessed to explore the capability

rir of the model when estimating the consequences of different manure management strategies

r I (Table 1) on a large-scale dairy cattle farm in Iran that owns over 9,000 cows (4,500 lactating

ro cows). To give an increased insight into the farm structure and technical conditions, some

17 characteristics of the target farm are presented in Table S18. In this target case, there is a

IIV market price for solid, liquid, composted manure and other products, as listed in Table S19.

ris To implement the model, real data from dairy farms were collected based on the input data

M19 requirements of the model. These data included herd characteristics, technical information

rr. related to housing type, manure collection, temperature, feed ingredients, etc. The manure

rr) treatment approaches were: manure collection (MC), transport 1 (T1), sand separation (Sand

rrr Sep.), AD, solid/liquid separation (S/L Sep.), composting (Comp.), storage (S), and transport

r to land (T2). A description of scenarios considered in this study is shown in Table 1.

Table 1. Scenarios of process analysis of a large-scale dairy farm in Iran

\begin{tabular}{|c|c|c|c|c|c|c|c|c|}
\hline Activities & Sc. $1(\mathrm{BC})$ & Sc. 2 & Sc. 3 & Sc. 4 & Sc. 5 & Sc. 6 & Sc. $7^{4}$ & Sc. $8^{5}$ \\
\hline $\mathrm{MC}$ & $x$ & $x$ & $x$ & $x$ & $x$ & $x$ & $x$ & $x$ \\
\hline T1 & $x$ & $x$ & $x$ & $x$ & $x$ & $x$ & $x$ & $x$ \\
\hline Sand Sep. ${ }^{1}$ & - & - & - & $x$ & $x$ & $x$ & $x$ & $x$ \\
\hline $\mathrm{AD}$ & - & - & - & - & - & $x$ & $x$ & $x$ \\
\hline S/L Sep. ${ }^{2}$ & - & $x$ & $x$ & $x$ & $x$ & $x$ & $x$ & $x$ \\
\hline Comp. ${ }^{3}$ & - & - & $x$ & - & $x$ & - & $x$ & $x$ \\
\hline$S^{6}$ & $x$ & $x$ & $x$ & $x$ & $x$ & $x$ & $x$ & $x$ \\
\hline $\mathrm{T} 2^{7}$ & $x$ & $x$ & $x$ & $x$ & $x$ & $x$ & $x$ & $x$ \\
\hline Scenario type & Baseline & Current & Current & Future & Future & Future & Future & Future \\
\hline $\begin{array}{l}\times \times \text { indicates in } \\
{ }^{1} \text { Mechanical sc } \\
{ }^{2} \text { Screw press } \\
{ }^{3} \text { Intensive win } \\
{ }^{4} \text { In Scs. 3, 5 an } \\
{ }^{5} \text { In Sc. 8, 100 }\end{array}$ & $\begin{array}{l}\text { uded process } \\
\text { d separation } \\
\text { row on bare s } \\
7,50 \% \text { of } m \\
\text { f }\end{array}$ & $\begin{array}{l}\text { Turni } \\
\text { re is se }\end{array}$ & $\begin{array}{l}\text { eratio } \\
\text { ed an }\end{array}$ & xcluded & $\begin{array}{l}\text { iders o } \\
\text { osted. }\end{array}$ & npc & site. & \\
\hline
\end{tabular}


${ }^{7}$ In Scs. 3, 5 and 7, transport is applied to the merged solid separated and composted manure.

$r r \leq \quad$ Sc. 1 is the baseline case (BC), whereby no manure treatment except storage is carried out

rro (Table 1). The two following scenarios (Sc. 2 and 3) show the effect of S/L separation (S/L

rr Sep.) for the total volume (Sc. 2) and for half of the volume in Sc. 3. In the surveyed dairy

TrV farms, it was observed that composting slurry was preferred over separation due to the higher

rrs cost of separation. Sand separation was added to Sc. 4 and 5. In scenarios 6 to 8, the impact

r $৭$ of $A D$ and an improved sand separation were investigated when different post digestion

rr. treatment techniques were combined. In Sc. 6, all digestate was separated and stored;

rT whereby in Sc. 8 all digestate was separated, the solid fraction was composted and the liquid

rre fraction was stored. Sc. 7 was an intermediate between Sc. 6 and Sc. 8 where $50 \%$ of manure

r was separated and stored, and the remained 50\% was composted. For all scenarios, it was

作 assumed that the solid separated fraction was stored for a definite period (two months), while

rro the composted manure was not stored and the merged solid separated and composted manure

צas transported to arable land.

rrv 2.7. Sensitivity analysis

Sensitivity analysis (SA) was carried out in this study to find out whether changes in rrq surrounding conditions have impact on the manure management systems that is being rะ. observed. Conditions that may have effect on manure management systems of this study can r $r \leqslant r \quad$ alternative scenarios), namely passive windrow composting instead of intensive windrow and $r \leqslant$ storage with cover instead of storage without cover (Hamelin et al., 2014). Second type was a $r \varepsilon \varepsilon$ one-at-a-time (OAT) approach (local sensitivity analysis) (Groen, 2016). This SA was $r \leqslant 0$ performed by varying some input parameters contributed to the technical, environmental and $r \leqslant \tau$ economic outputs of future scenarios (Scs.6-8) by $\pm 10 \%$. The input parameters for sensitivity 
$r \leqslant \vee$ analysis were selected accurately to consider all influential parameters. Details behind the

$r \leqslant \wedge$ modelling of sensitivity analyses are presented in the SI.

\section{rะq 3. Results}

ro. Different scenarios of manure management on a large-scale dairy farm in Iran were ro) investigated using a framework model, assessing the technical (mass balance), environmental ror and economic aspects. The results are presented for different above mentioned aspects as ror follows:

\section{ros 3.1. Mass balance of nutrients}

The characteristics of the excreted manure (N, P, K, C content) and manure properties are presented in Table S20. For the selected farm, the total manure excretion, amounts of $\mathrm{N}, \mathrm{P}, \mathrm{K}$, fraction of TAN in the excreted $\mathrm{N}$ and the $\mathrm{C}: \mathrm{N}$ ratio were calculated as 504.6, 2.9, 0.24, $1.8 \mathrm{t}$ $\mathrm{d}^{-1}, 0.7$ and 7.467

พา.

A MB for the total mass and manure quality for scenarios 1, 2 and 3 is presented in Fig. 3, and for scenarios 4-8 in Figs. S2 and S3. The values of the total mass are expressed as $\mathrm{t} \mathrm{d}^{-1}$ and the quality of manure is expressed as $\mathrm{kg} \mathrm{t}^{-1}$ of manure at the end of each step. The balance shows how different methods of manure processing affect losses compared to the other scenarios. Sand separation saved large amounts of sand estimated at over $164 \mathrm{~kg} \mathrm{t}^{-1}$ of excreted manure in Sc. 4 and $82 \mathrm{~kg} \mathrm{t}^{-1}$ in Sc. 5, reduced the manure volume and caused no nutrients to be lost. S/L separation hardly affected nutrient losses while it reduced further transport problems, as the liquid fraction could be applied at the dairy farm, whereas the solid fraction could be exported. In Sc. 6, 7 and 8 where AD was applied, there was a significant reduction in carbon compared to the other pathways (over $50 \%$ in the final product). Although, the carbon decomposition rate was high during composting, a large amount of carbon was oxidized and emitted as $\mathrm{CO}_{2}$. Comparing Sc. 6, 7 and 8 shows that about $28 \%$, $24 \%$ and $29 \%$ of nitrogen was decomposed and volatilized, which increased the $\mathrm{N}$ loss. The 
rVr losses from storage were affected by the type and quality of the manure, while the loss of $r v r$ nutrients in the solid fraction was lower than the slurry. For example, comparing Sc. 2 with $r \vee \leqslant$ the baseline case, the total loss was reduced by about $18 \%$. 


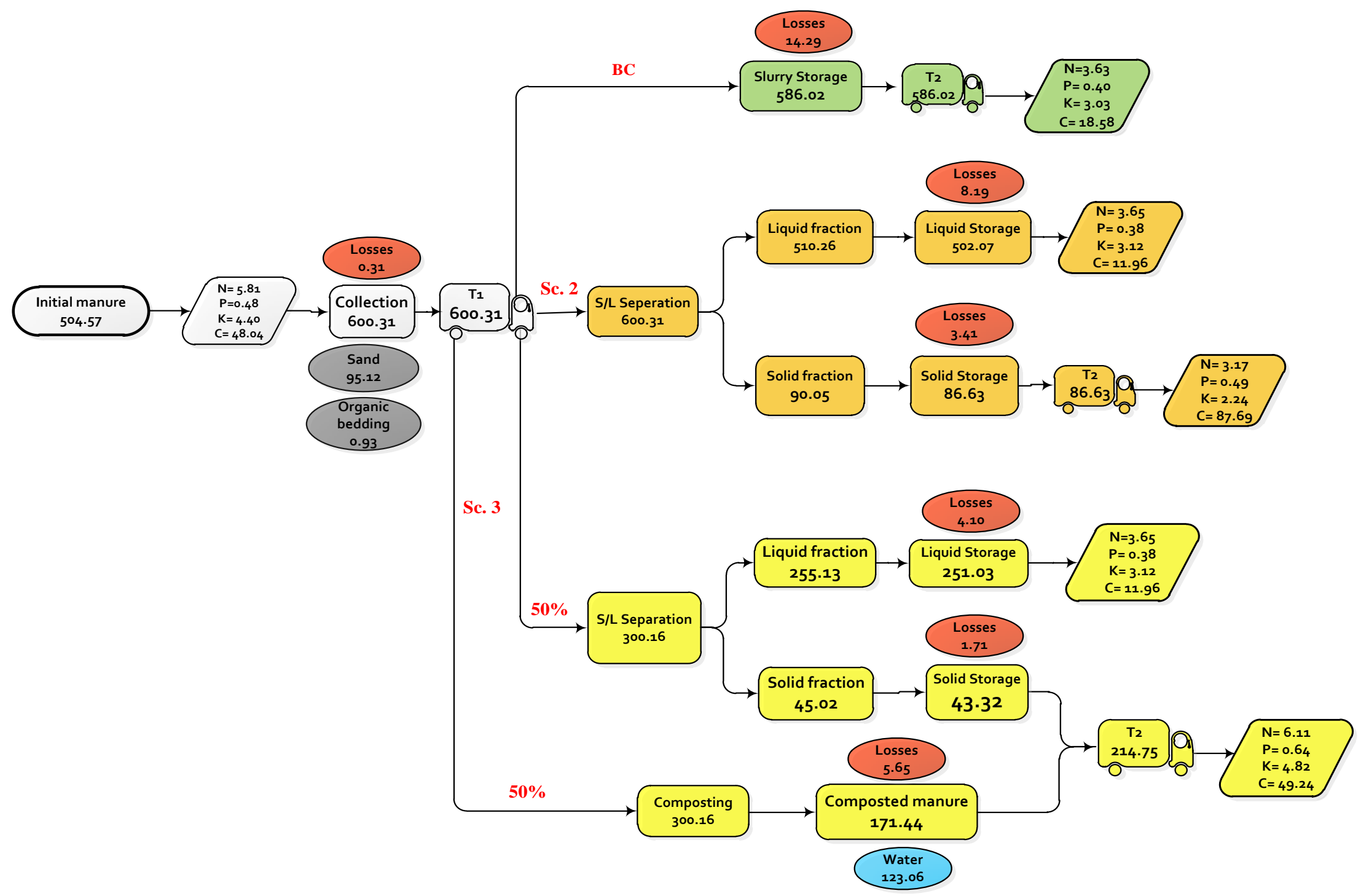

Fig. 3. Mass balance through Sc. 1, Sc. 2 and Sc. 3. All values are in $\mathrm{t} \mathrm{d}^{-1}$ except for the values in trapezoids in $\mathrm{kg} \mathrm{t}^{-1}$. 
rvo

rVT

rVV

rYA

rVq

rA.

rNI

rAT

rᄉ

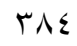

rio

rᄉT

rAv

rNA

rᄉq

$r q$.

rq)

rar

rat

rqะ

r9o

ra9

rqv

rq1

\subsection{Environmental assessment}

GHG emissions are presented in two categories: fossil based and biotic based emissions. GHG emissions were converted to the 100-year time horizon global warming potential (GWP) using the appropriate coefficients (298 and $34 \mathrm{~kg} \mathrm{CO}_{2 \mathrm{eq}}$ for $\mathrm{N}_{2} \mathrm{O}$ and $\mathrm{CH}_{4}$ ) (Stocker et al., 2013). Results are expressed per $t$ of excreted manure. Fig. 4 represents the global warming potential of all scenarios.

\subsubsection{Fossil carbon dioxide emissions}

The fossil $\mathrm{CO}_{2}$ emissions $\left(\mathrm{CO}_{2-\mathrm{f}}\right)$ were in the range of $0.8-4.5 \mathrm{~kg} \mathrm{CO}_{2 \mathrm{eq}} \mathrm{t}^{-1}$ that have contributed least to the total emission. In the case of $\mathrm{AD}, 42.4 \mathrm{~kg} \mathrm{CO}_{2 \mathrm{eq}}$ may be avoided by using produced biogas to generate electricity and heat by a CHP.

\subsubsection{Biogenic methane emissions}

$\mathrm{CH}_{4}$, mainly produced by storage of slurry in Sc. 1, was the major source of emissions, while Sc. 2 and 4 ranked next in emitting $\mathrm{CH}_{4}$ from the liquid manure storage. During Scs. 6, 7 and 8 , results showed that there was a potential for $\mathrm{CH}_{4}$ formation in the storage of liquid fraction following AD. This considerable share of $\mathrm{CH}_{4}$ was mainly due to the anaerobic conditions in pits/silos and the limited retention time in the AD equipment (26 days). Separation of manure reduces the methane emission as shown in all other scenarios. Composting of the manure, which is practised for $50 \%$ of the volume in Scs. 3, 5 and 7 showed a reduction in $\mathrm{CH}_{4}$ emissions, compared to their neighbouring scenarios 2, 4 and 6 , where all manure was separated to liquid and solid fraction. A reduction of $\mathrm{CH}_{4}$ in these schemes was related to the type of the composting treatment. The $\mathrm{CH}_{4}$ emission calculated for scenario 8 was comparable to scenario 7, due to the fact that all digestate was separated in Sc. 8 and the liquid fraction had a large contribution to $\mathrm{CH}_{4}$ emissions.

\subsubsection{Biogenic nitrous oxide emissions}


५ १९ $\mathrm{N}_{2} \mathrm{O}$ was substantially emitted through scenarios where composting was applied. $\mathrm{N}_{2} \mathrm{O}$ was «.. estimated to be $35.1 \mathrm{~kg} \mathrm{CO}_{2 \text { eq }} \mathrm{t}^{-1}$ in Sc. 3,5 and 7 and $17.8 \mathrm{~kg} \mathrm{CO}_{2 \text { eq }} \mathrm{t}^{-1}$ in Sc. 8 caused by a «. lower $\mathrm{N}$ content of the solid fraction, compared to the liquid fraction. Separating manure to E.r the solid fraction (C-rich and $\mathrm{N}$-poor fraction) and liquid fraction (C-poor and $\mathrm{N}$ rich E.r fraction) followed by solid manure composting reduced $\mathrm{N}_{2} \mathrm{O}$ emissions and reduced the $\varepsilon \cdot \varepsilon \quad$ amount of $\mathrm{CH}_{4}$ in the liquid manure storage tank. The sum of $\mathrm{N}_{2} \mathrm{O}$ emissions from the storage ¿.० of solid and liquid fractions was equal in scenarios 2 and 4 , whereby $16 \%$ of that was ¿. 7 attributed to the storage of the solid fraction. The same trend was observed in scenarios 6 to 8 $\varepsilon \cdot \vee \quad$ showing the efficiency of separation slurry into N-rich liquid fraction.

\section{$\varepsilon \cdot \wedge \quad$ 3.2.4. Total emissions}

๕.9 Results indicated that scenarios including AD (Scs. 6, 7 and 8) had the lowest total «. emissions due to the capture of methane emissions in the digester and avoidance of fossil¿1) fuel-related emissions due to generating electricity from biogas. Of these three scenarios, Sc. \&Ir 6 had the lowest GWP impact amounted to $27.7 \mathrm{~kg} \mathrm{CO}_{2 \mathrm{eq}} \mathrm{t}^{-1}$ and significantly lowest $\mathrm{N}_{2} \mathrm{O}$

¿ाT emissions. Emissions from Sc. 1 were estimated to be $162 \mathrm{~kg} \mathrm{CO}_{2 \mathrm{eq}} \mathrm{t}^{-1}$, contributing most to §) $\varepsilon$ the GWP impact. 


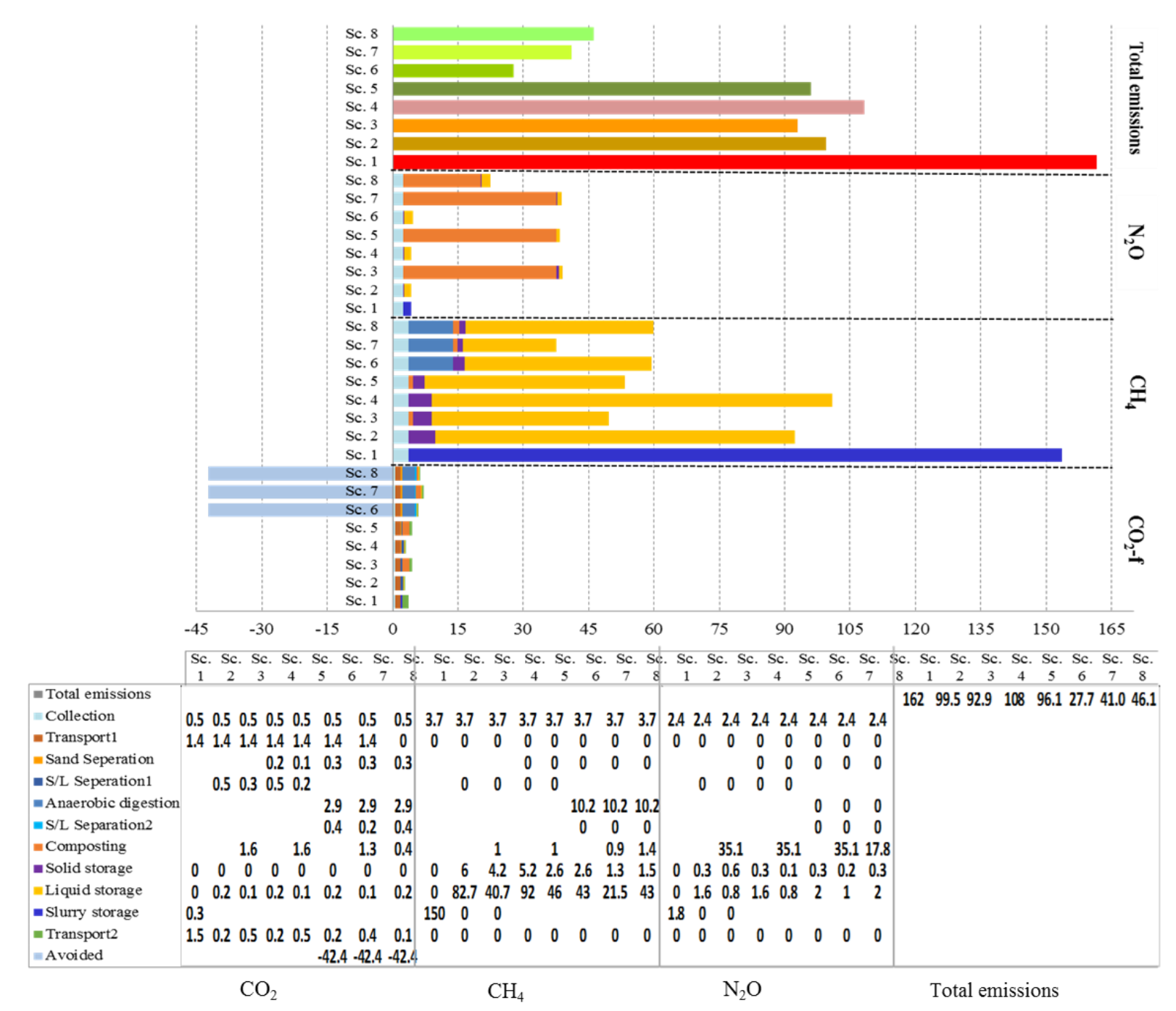

Fig. 4. Process based analysis of GHG emissions $\left(\mathrm{kg} \mathrm{CO}_{2 \mathrm{eq}} \mathrm{t}^{-1}\right)$ for all steps of the MMC scenarios.

$\varepsilon 10$

$\varepsilon r$. half of the manure, less nitrogen was exposed to $\mathrm{N}$ decomposition during storage and higher

$\{r) \quad N$ recovery was attained. In scenarios involving $A D$, the ratio between $N_{\text {org }}$ and $N_{\text {min }}$ changed

\&rr in favour of plant-available ammonium. All the scenarios showed a constant and high level of

¿rr P recovery since phosphorus is hardly soluble and leached. The level of $\mathrm{K}$ recovery was less 
¿rs than P (about 80\%). When separation and composting was applied to the AD digestate (Sc.

sro 8), the recovery decreases to about $78 \%$. The higher recovery rate in Scs. 3, 5 and 7 , \&ry compared to Scs. 2, 4 and 6, may be due to the fact that in the latter 3 scenarios, less manure $\sum r \vee \quad$ was stored, whereas more K may have been lost through runoff and leaching. The MNRE of ¿r^ C was very low for all scenarios suggesting that carbon conversion took place in all types of \& $r q$ manure treatment, whereas the carbon conversion in the AD scenarios (Scs. 6, 7 and 8) $\varepsilon r$. $\quad$ showed a stronger decrease of carbon recovery. The lowest MNRE rates for $\mathrm{C}$ were found in \&r) Sc. $8(35 \%)$ with separation and intensive composting of digestate, which ended up with \& \& composting of the C-rich solid fraction where $\mathrm{C}$ conversion via composting was intensified.

$\varepsilon r \varepsilon$ Meanwhile, the liquid fraction of the manure was stored. The liquid fraction had a large \&ro contribution to $\mathrm{CH}_{4}$ emissions with a reduced $\mathrm{C}$ recovery. Regarding $\mathrm{C}$ recovery, the highest \&тч MNRE was found in scenario 2 (56\%), where manure separation was practised without active $\varepsilon r v$ composting.

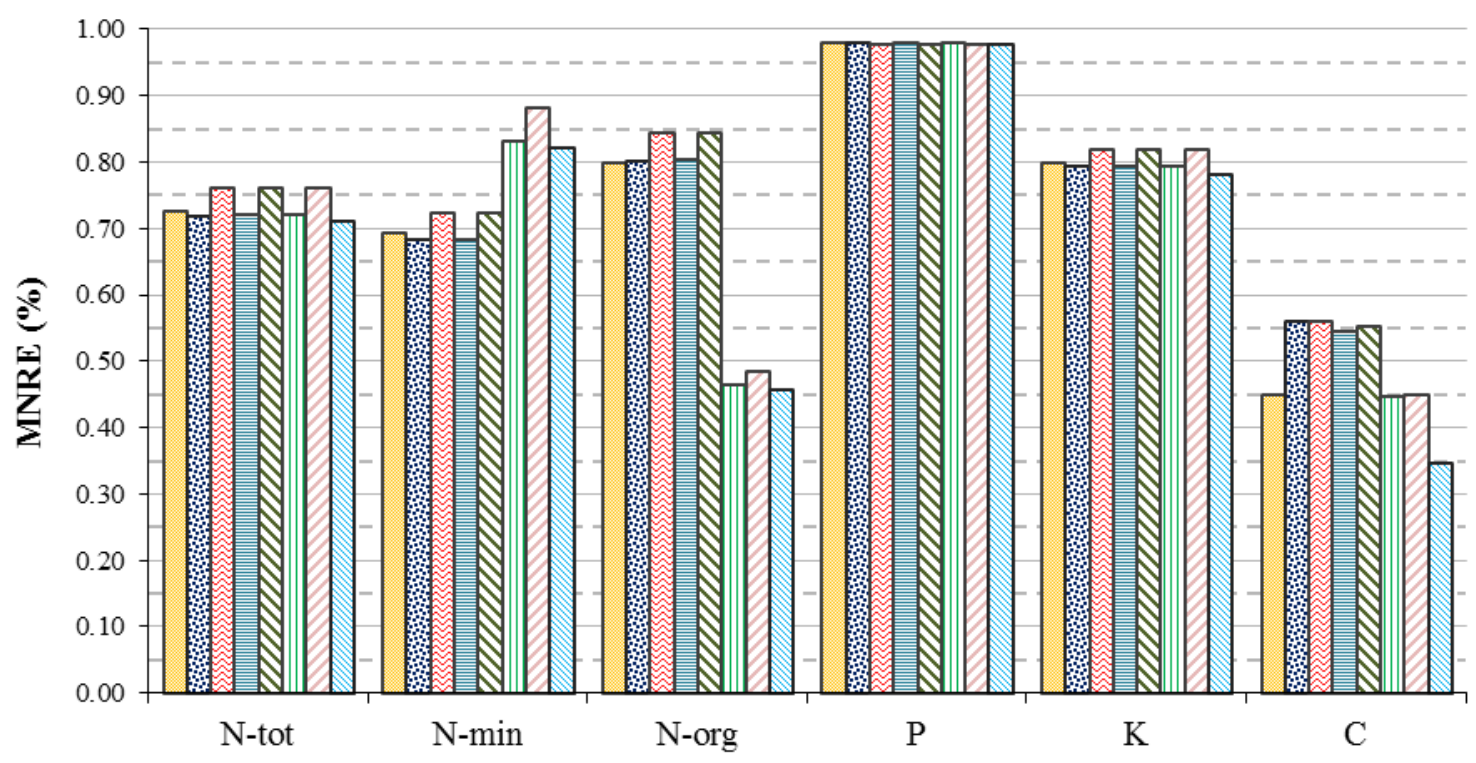

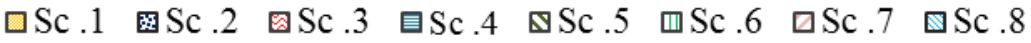

Fig. 5. The Manure Nutrient Recovery Efficiency for N (total, organic and mineral), P, K and $\mathrm{C}$ at the farm level for different scenarios. 
A cost-benefit analysis was performed by the TECBA-MMC tool using the data provided by the study farm. The results of this section are presented in Table 2. Financial indices were calculated to investigate the feasibility of each scenario. The attractiveness of the investment projects is clearly shown by the positive net present value (NPV), the higher (greater than one) profitability index (PI), and the higher internal rate of return (IRR) (greater than the discount rate of $20 \%$, in this case). As shown in Table 2, scenarios that excluded AD showed higher profitability indices, while more GHG emissions were produced. The highest NPV was achieved in Sc. 1 as the lowest total investment cost (TIC) was charged. As shown in Table 2, Scs. 4 and 5 which include sand separation had lower economic indices, while the avoided costs due to the sand recovery and maintenance had been taken into account. Therefore, the added weight of sand mixed with manure sold to arable lands, regardless of manure quality, would lead to the higher profitability. Comparing Scs. 6-8 for costeffectiveness of $\mathrm{AD}$ showed the financial feasibility of these scenarios. This economic viability was due to the high price of electricity sold to the grid with the current high subsidy policy on renewable energy production in Iran. This has motivated dairy farmers, especially those on large-scale farms, to start investing on such projects with an average payback period of two years. There are other benefits to biogas production such as social impacts, which have not been quantified in this study, such as improved sanitation on the farm, health implications, more job opportunities and the economic growth of the area. The post digestion treatment techniques and the corresponding by-products resulted in the difference in profitability of these projects. For example, Sc. 7 was shown to be more profitable than Sc. 6 and 8 since a greater amount of solid digestate was produced (about $60 \%$ and $78 \%$ more than the other two scenarios).

Table 2. Calculated GHG, total investment costs and financial indices of the manure treatment techniques

\begin{tabular}{cccccccccc}
\hline Criteria & Unit & Sc. 1 & Sc. 2 & Sc. 3 & Sc. 4 & Sc. 5 & Sc. 6 & Sc. 7 & Sc. 8 \\
\hline Separation & $\%$ & 0 & 100 & 50 & 100 & 50 & 100 & 50 & $100^{*}$ \\
Composting & $\%$ & 0 & 0 & 0 & 0 & 0 & 0 & 50 & $100^{* *}$
\end{tabular}




\begin{tabular}{lccccccccc} 
GHG total & $\mathrm{kg} \mathrm{CO}_{2} \mathrm{t}^{-1}$ & 161.6 & 99.5 & 92.9 & 108.2 & 96.1 & 27.7 & 41 & 46.1 \\
TIC & $\mathrm{K€}$ & 43.11 & 66.67 & 148.94 & 92.34 & 174.6 & 2558.8 & 2639 & 2629.2 \\
BCR & - & 113.73 & 22.08 & 24.21 & 18.03 & 20.74 & 2.34 & 4.77 & 2.09 \\
IRR & $\%$ & 50 & 38 & 39 & 35 & 38 & 22 & 27 & 22 \\
PBP & $\mathrm{y}$ & 0.01 & 0.07 & 0.06 & 0.1 & 0.07 & 2.46 & 1.08 & 2.74 \\
PI & - & 347.98 & 62.83 & 75.7 & 43.16 & 63.11 & 1.72 & 3.9 & 1.55 \\
NPV & $\mathrm{K} €$ & 15724.8 & 3560 & 4008.0 & 3369.3 & 3901.5 & 3032.3 & 9494.1 & 3312.2 \\
\hline
\end{tabular}

* This is applied to $100 \%$ of digestate

** This is applied to $100 \%$ of solid fraction

¿ 3.5. Sensitivity analysis results

¿7r Two types of sensitivity analyses were carried out to determine the robustness of the

$\varepsilon \tau$ results by changing two alternative manure treatment methods and varying sensible

¿70 parameters. The effect on GWP, avoided emissions, NPV and nutrient availability for Scs. 6-

ะ 7 were reported. Results for alternative composting are represented in Fig. 6 and for other

¿TV scenarios are presented in Figs. S4-S7.

¿7^ Passive composting instead of intensive composting would be an advantage for better ะ79 environmental performance since passive method is a type of windrow composting with ¿マ. much less turning schedule. For passive composting performed in Scs.3, 5 and 7, Fig. 6 \&v highlights a decrease in total GWP through all scenarios (around 34\%). This result is in Evr agreement with the findings of Hao et al. (2001). Higher $\mathrm{N}_{2} \mathrm{O}$ emission for the intensive ¿vr composting has been decreased in much larger magnitude during passive composting method $\varepsilon \vee \varepsilon \quad$ (around $87 \%$ ). Less $\mathrm{N}_{2} \mathrm{O}$ emissions was reported when static pile with less frequent aeration ¿vo (passive) method was compared with intensive composting (Szanto et al., 2007). The detailed $\sum \vee \uparrow$ results are described in the SI. 


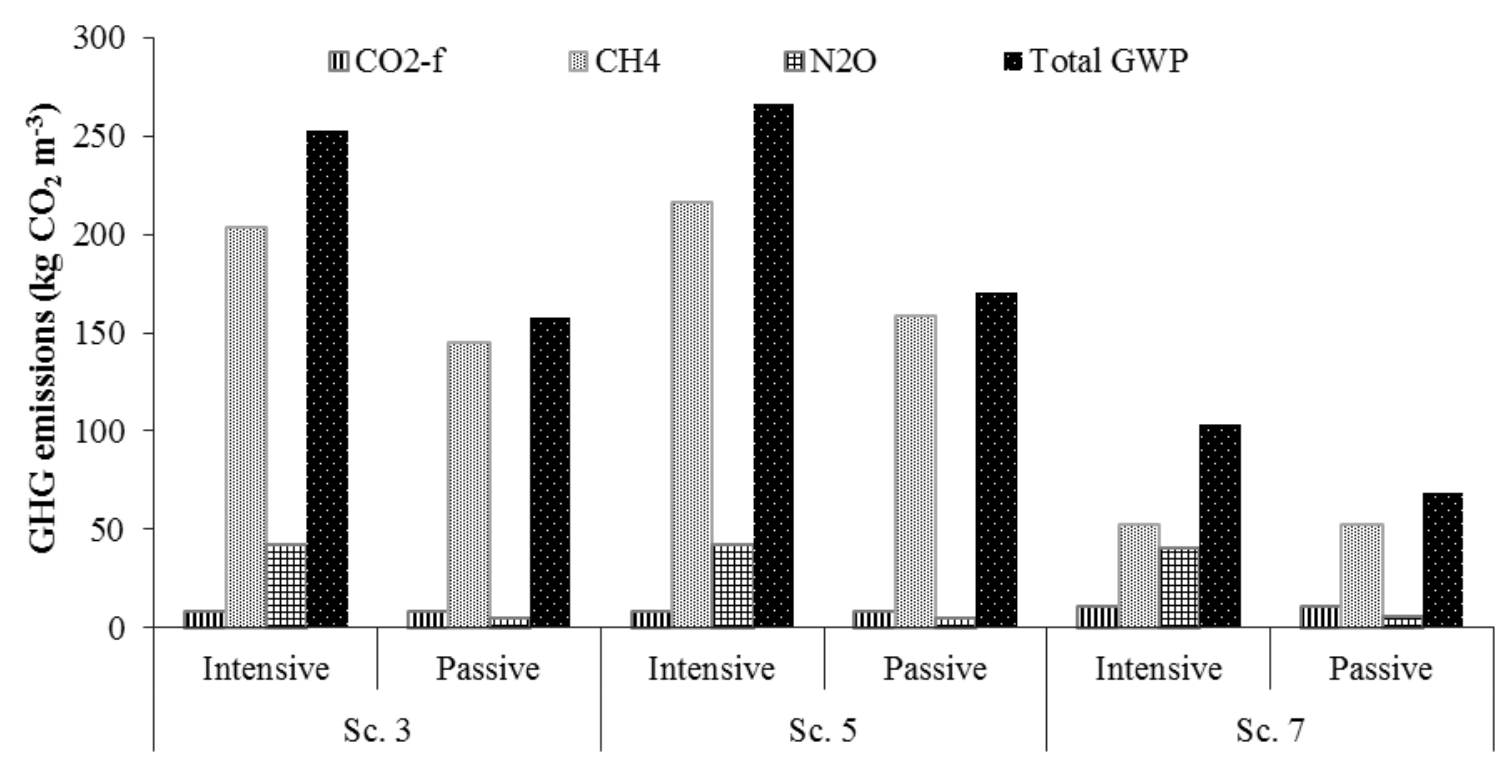

Fig. 6. Results for GHG emissions for the sensitivity analysis performed with passive composting instead of intensive composting

$\varepsilon \vee V$

$\varepsilon \vee \wedge$

$\sum \vee 9$

$\varepsilon \wedge$.

$\varepsilon \wedge r$

$\varepsilon \wedge r$

\section{Discussion}

The technical, environmental and economic aspects of different manure management systems were assessed so that the eco-friendly scenarios promoting circular economy and recovering the essential nutrients in organic fertilizers were identified. Providing the subsequent technical, environmental and economic analysis, a comprehensive overview of the evaluated scenarios using the TECBA-MMC model is given in Table 3 . The negative and values show deteriorations and improvements when comparing each scenario with the BC. It should be noted that a negative NPV does not reflect a net loss; instead, it demonstrates the change to the $\mathrm{BC}$.

Table 3. Changes in the performance of each scenario compared to the $\mathrm{BC}^{*}$

\begin{tabular}{lcccccccc}
\hline Scenario & Unit & Sc. 2 & Sc. 3 & Sc. 4 & Sc. 5 & Sc. 6 & Sc. 7 & Sc. 8 \\
\hline Recovery of $\mathrm{N}_{\text {tot }}$ & $\%$ & $-0.68^{* *}$ & 4.8 & -0.68 & 4.8 & -0.68 & 4.8 & -2.1 \\
Recovery of P & $\%$ & 0 & -0.2 & 0 & -0.2 & 0 & -0.2 & -0.41 \\
Recovery of K & $\%$ & -1.25 & 2.5 & -1.25 & 2.5 & -1.25 & 2.5 & -2.5 \\
Recovery of C & $\%$ & 24.4 & 24.4 & 20 & 22.2 & 0 & 0 & -24.4 \\
Total GHG & $\%$ & -38.5 & -42.6 & -32.2 & -40.7 & -83 & -74.7 & -71.5 \\
NPV & $\%$ & -77.4 & -74.5 & -78.6 & -75.2 & -80.7 & -39.6 & -78.9 \\
\hline
\end{tabular}

${ }^{*}$ Difference $=[\mathrm{B}-\mathrm{A} / \mathrm{A}] \times 100$

${ }^{* *}$ Negative values shows deterioration and positive values shows improvement. 
o..

0.1

$0 . r$

The results showed that although the sand separation process (in Sc.4 and Sc. 5) did not significantly affect emissions (compared to Sc. 2 and Sc. 3), it saved bedding sand, transport and equipment amortization costs. Taking into account the avoided costs and emissions of sand mining could affect the results of this study. Sand separation is a crucial process for the efficiency of the $\mathrm{AD}$ process due to sand sedimentation and time losses for removing sediments in a continuous AD process. Regarding sand separation, no relevant evidence in previous studies was found for comparison purposes.

The large reduction of emissions in the $\mathrm{AD}$ scenarios $(71.5 \%$ - 83\%) may have been caused by capturing methane emissions and saving fossil fuels. Since the capture of methane by $\mathrm{AD}$ can be considered as avoided emissions, it cannot be used as a negative value in the calculations. The AD process optimised methane production from manure. The savings in fossil fuels due to producing electricity and utilising heat was used as a negative figure in the calculations. Comparing the GHG emissions of the AD in scenario 6 with the baseline scenario showed a reduction of emissions to $134.3 \mathrm{~kg} \mathrm{CO}_{2 \mathrm{eq}} \mathrm{t}^{-1}$. Pardo et al. (2017) reported a reduction of $101 \mathrm{~kg} \mathrm{CO}_{2 \mathrm{eq}} \mathrm{t}^{-1}$ for a one stage mesophilic $\mathrm{AD}$ followed by open storage in temperate climatic conditions. Based on these results, the carbon conversion and $\mathrm{CH}_{4}$ capturing occurred in the $\mathrm{AD}$ lead to a reduced decomposition rate of carbon in the subsequent storage process. In this study, a reduction of $9 \%$ VS in digestate, relevant to the change in $\mathrm{C}$ amount, was estimated. Pardo et al. (2017) calculated this reduction to be $7 \%$. The shift from $\mathrm{N}_{\text {org }}$ to $\mathrm{N}_{\min }$ during the $\mathrm{AD}$ process was estimated to be $36 \%, 40 \%$, and $36 \%$, showing the higher $\mathrm{NH}_{4}$ content in the digested slurry. This change has been reported by Aguirre-Villegas et al. (2014) (68\%) and Möller et al. (2008) (24\%).

Of the options found to reduce emissions and costs, separation of the slurry or the digested slurry into solid and liquid fraction was best. Enhancing the quality of manure streams is an additional benefit of this technique. Nutrients such as $\mathrm{N}$ and $\mathrm{P}$ may be removed along with 
01) the solid stream and can be further used as fertilizer or bedding. The same implication was olr reported in previous studies by Hjorth et al. (2010) and Aguirre-Villegas and Larson (2017). or Another important aspect of this was the fate of the liquid fraction of mechanical separation. 0) $\leqslant$ When applied at the dairy farm, a certain area of land is needed for application in an 010 agronomic way and it has to match the crop requirements. Otherwise, it should be transported 017 to neighbouring lands or sent to further separation devices for reverse osmosis to produce olv water that can be discharged to surface water. Insufficient land availability runs the risk of an 011 over application of nutrients.

019 The results show that composting of manure may be a cost saving action, due to the or. volume reduction for transportation, caused by evaporation of water and the oxidation of or) carbon. This is done at the expense of nitrogen and potassium recovery and increasing nitrous orr oxide emissions, and in the meantime reducing methane emissions. Tiquia et al. (2002) orr reported great $\mathrm{C}$ losses in composting methods included windrow turnings. There are ors additional studies, which have reported the high $\mathrm{C}$ and $\mathrm{N}$ losses during composting (Hao et oro al., 2001; Sommer, 2001). Due to investment limitations, farmers may prefer to select ory composting. This method is not recommended when the nutrient recovery in the final manure orv is substantial due to higher risk of $\mathrm{N}$ and $\mathrm{K}$ losses. There exists a trade-off between these or^ conflicting objectives, i.e. maximum nutrients recovery efficiency, minimum environmental orq impacts and maximum financial profitability.

or. This study showed that the developed model may be utilised as a helpful tool for assessing or) technical, environmental and economic effects of manure management options; however, this orr model still has its limitations regarding ensuring the best solution due to a number of uncertainties. The main uncertainties in the results of this study are related to the robustness or 5 of the data derived from literature and the emission factors used. There were a number of oro limitations related to data requirements. In this regard, local data collection for the feed ration 
orr of cows, nutritional value of the feed, investment costs and capacities to implement the new orv technologies is necessary. Selecting suitable coefficients and emissions factors to specifically ors meet the dairy farming situation in Iran was the other limitation of this study.

orq The application of the model in evaluating the performance of eight scenarios throughout ๑s. the MMC from manure collection to transport of manure to arable lands represents the cost0\&) effectiveness and environmental impacts in supporting decision makers for choosing the best o $\{r$ options that meet agronomic, environmental and economic goals. The approach adopted and o\&r the model developed can be applied for other managerial decisions, herd compositions, $0 \leqslant$ feedstock mixtures, while considering technical, environmental and economic aspects. This 0 « study presents an assessment of different manure management scenarios considering three $0 \leq 7$ individual perspectives and it still lacks the integration of three aspects. In this context, this $0 \leqslant \vee$ study may be extended to a multi criteria decision-making analysis for selecting the best $0 \leqslant \wedge$ scenarios considering these three aspects. For future works, the model may be extended to $0 \leqslant 9$ incorporate more alternative strategies of manure processing. For example, different manure ๑0. separation techniques such as reverse osmosis and ultrafiltration, storage facilities, codigestion of manure with other locally available organic wastes could be considered. Social assessment is recommended to be integrated into this model in future works to achieve a sustainable life cycle of manure management.

The sensitivity analyses performed in this study showed the most effective parameters on the most important indicators of this study. Dry matter was influential on GWP and the annual discount rate and loan rate on biogas projects had a great impact on NPV. Covered storage achieved higher environmental impact reduction. The overall effects on GWP, NPV and other management indicators will be analysed in future works.

\section{Conclusion}


07. Manure management and processing scenarios in large-scale dairy farming were evaluated

by developing a process-based model considering the technical, environmental and economic performance of an entire chain. The model was shown to operate effectively and has shown its value in a described case study. The results of applying the model to the study farm presents the efficiency of manure treatment techniques in a whole MMC, which will aid farmers, decision makers and investors to understand the performance of each scenario and improve their practices to reduce GHG emissions. The main key factors for the best manure management methods which were analysed in this study consisted technical, environmental and economic aspects.

To predict the quality of the final product of each scenario, a mass-balance approach was employed. As a result, a decision maker (or farmer) can select the suitable manure treatment scenario considering the farm condition such as soil characteristics and plant requirement. Based on the results, sand separation did not significantly affect emissions, quality of the endproduct and could be quite efficient in reducing energy consumption related to the mining, processing and transporting of sand, and reducing maintenance and transport costs. In terms of GHG emissions, scenarios 1-3 had reasonable increase of environmental emissions. In contrast, the results showed no contribution of sand separation to environmental burdens. Composting reduced transport costs and resulted in low recoveries of $\mathrm{C}, \mathrm{N}$ and $\mathrm{K}$ and high levels of nitrous oxide emissions that reduces the agronomic value of the final compost. Composting would be a good solution when manure needs to be exported and the quality of compost is not important.

In general, S/L separation was very beneficial to emission mitigation especially methane, reducing transport cost and preventing over fertilization but still greatly contributing to nitrous oxide emission when combined with composting. AD was found as the best option to reduce emissions. Although $\mathrm{AD}$ is a costly manure strategy, the current situation in Iran 
ฯ. Acknowledgments

T. The authors express their appreciation to Dr. Karin Groenestein, Dr. Roland Melse, and Ing.

T.r Fridtjof de Buisonje for their stimulating discussion and remarks. We also thank to Dr.

ฯ. $\{$ Bastiaan Meerburg, the head of Livestock and environment department, Wageningen

7.0 University and Research for all of his supports in this project.

\section{^. $\quad$ References}

१.V Aguirre-Villegas, H.A., Larson, R.A., 2017. Evaluating greenhouse gas emissions from dairy 1.1 manure management practices using survey data and lifecycle tools. Journal of Cleaner

7. 9 Production 143, 169-179. 
Aguirre-Villegas, H.A., Larson, R., Reinemann, D.J., 2014. From waste-to-worth: energy, emissions, and nutrient implications of manure processing pathways. Biofuels, Bioproducts and Biorefining 8(6), 770-793.

Araji, A., Stodick, L., 1990. The economic potential of feedlot wastes utilization in agricultural production. Biological Wastes 32(2), 111-124.

Audsley, E., Wilkinson, M., 2014. What is the potential for reducing national greenhouse gas emissions from crop and livestock production systems? Journal of Cleaner Production 73, 263-268.

Blumenstein, B., Siegmeier, T., Selsam, F., Möller, D., 2018. A case of sustainable intensification: Stochastic farm budget optimization considering internal economic benefits of biogas production in organic agriculture. Agricultural Systems 159, 78-92.

Burney, J., Lo, K., Carson, W., 1980. Dairy waste management system selection by network analysis. Canadian Agricultural Engineering 22(1), 41-47.

Chadwick, D., Wei, J., Yan'an, T., Guanghui, Y., Qirong, S., Qing, C., 2015. Improving manure nutrient management towards sustainable agricultural intensification in China. Agriculture, Ecosystems and Environment 209, 34-46.

Chianese, D., Rotz, C., Richard, T., 2009. Simulation of carbon dioxide emissions from dairy farms to assess greenhouse gas reduction strategies. Transactions of the ASABE 52(4), 13011312 .

De Vries, J., Vinken, T., Hamelin, L., De Boer, I., 2012. Comparing environmental consequences of anaerobic mono-and co-digestion of pig manure to produce bio-energy-a life cycle perspective. Bioresource Technology 125, 239-248.

Ecoinvent3.3, 2016. Ecoinvent ${ }^{\circledR S}$ Swiss Center for Life Cycle Inventories. http://www.ecoinvent.org/database/ecoinvent-33/ecoinvent-33.html. (Accessed 06 June 2018).

Gharaei, A., Pasandideh, S.H.R., 2017. Four-echelon integrated supply chain model with stochastic constraints under shortage condition. Industrial Engineering \& Management Systems 16(3), 316-329.

Gharaei, A., Pasandideh, S.H.R., Arshadi Khamseh, A., 2017. Inventory model in a fourechelon integrated supply chain: Modeling and optimization. Journal of Modelling in Management 12(4), 739-762.

Groen, E.A., 2016. An uncertain climate: the value of uncertainty and sensitivity analysis in environmental impact assessment of food. $\mathrm{PhD}$ thesis. Wageningen University, Wageningen, the Netherlands.

Hamelin, L., Naroznova, I., Wenzel, H., 2014. Environmental consequences of different carbon alternatives for increased manure-based biogas. Applied Energy 114, 774-782.

Hao, X., Chang, C., Larney, F.J., Travis, G.R., 2001. Greenhouse gas emissions during cattle feedlot manure composting. Journal of Environmental Quality 30(2), 376-386. 
I£^ Hjorth, M., Christensen, K.V., Christensen, M.L., Sommer, S.G., 2010. Solid-liquid $1 \leqslant 9$ separation of animal slurry in theory and practice. Agronomy for Sustainable Development 7. $30(1), 153-180$.

Hoseini Shekarabi, S.A., Gharaei, A., Karimi, M., 2018. Modelling and optimal lot-sizing of integrated multi-level multi-wholesaler supply chains under the shortage and limited warehouse space: generalised outer approximation. International Journal of Systems Science: Operations \& Logistics, 1-21.

IPCC, 2006. Agriculture, forestry and other land use, Guidelines for National Greenhouse Gas Inventories, vol. 4, chapter 10. http://www.ipcc-nggip.iges.or.jp/public/2006gl/vol4.html (Accessed 06 June 2018).

Jørgensen, P.J., 2009. Biogas- green energy, Process, Design, Energy supply, Environment, 2 ed. Faculty of Agricultural Sciences, Aarhus University, Danmark.

Junior, C.C., Cerri, C.E., Pires, A.V., Cerri, C.C., 2015. Net greenhouse gas emissions from manure management using anaerobic digestion technology in a beef cattle feedlot in Brazil. Science of the Total Environment 505, 1018-1025.

MacLeod, M., Vellinga, T., Opio, C., Falcucci, A., Tempio, G., Henderson, B., Makkar, H., Mottet, A., Robinson, T., Steinfeld, H., 2018. Invited review: A position on the Global Livestock Environmental Assessment Model (GLEAM). Animal 12(2), 383-397.

Makara, A., Kowalski, Z., 2018. Selection of pig manure management strategies: case study of polish farms. Journal of Cleaner Production 172, 187-195.

Melse, R., de Buisonje, F., 2015. Quick calculation tool for manure separation and distribution of mass, minerals and dry matter. http://sdddc.org/en/download/detail-155.aspx. (Accessed 06 June 2018).

Mezzullo, W.G., McManus, M.C., Hammond, G.P., 2013. Life cycle assessment of a smallscale anaerobic digestion plant from cattle waste. Applied Energy 102, 657-664.

Möller, K., Stinner, W., Deuker, A., Leithold, G., 2008. Effects of different manuring systems with and without biogas digestion on nitrogen cycle and crop yield in mixed organic dairy farming systems. Nutrient Cycling in Agroecosystems 82(3), 209-232.

Montalvo, C., 2008. General wisdom concerning the factors affecting the adoption of cleaner technologies: a survey 1990-2007. Journal of Cleaner Production 16(1), S7-S13.

Monteny, G., Groenestein, C., Hilhorst, M., 2001. Interactions and coupling between emissions of methane and nitrous oxide from animal husbandry. Nutrient Cycling in Agroecosystems 60(1-3), 123-132.

Nennich, T., Harrison, J.H., Vanwieringen, L.M., Meyer, D., Heinrichs, A., Weiss, W.P., StPierre, N.R., Kincaid, R., Davidson, D.L., Block, E., 2005. Prediction of manure and nutrient excretion from dairy cattle. Journal of Dairy Science 88(10), 3721-3733.

NRC, 2001. Nutrient requirements of dairy cattle, 7 ed. National Academies Press, Natl. Acad. Press, Washington, DC. 
O'Mara, F.P., 2011. The significance of livestock as a contributor to global greenhouse gas emissions today and in the near future. Animal Feed Science and Technology 166, 7-15.

Oenema, O., Oudendag, D., Velthof, G.L., 2007. Nutrient losses from manure management in the European Union. Livestock Science 112(3), 261-272.

Pardo, G., Moral, R., del Prado, A., 2017. SIMSWASTE-AD-A modelling framework for the environmental assessment of agricultural waste management strategies: Anaerobic digestion. Science of the Total Environment 574, 806-817.

Petersen, S.O., Sommer, S., Béline, F., Burton, C., Dach, J., Dourmad, J., Leip, A., Misselbrook, T., Nicholson, F., Poulsen, H.D., 2007. Recycling of livestock manure in a whole-farm perspective. Livestock Science 112(3), 180-191.

Pratt, C., Redding, M., Hill, J., Jensen, P.D., 2015. Does manure management affect the latent greenhouse gas emitting potential of livestock manures? Waste Management 46, 568-576.

Reidy, B., Dämmgen, U., Döhler, H., Eurich-Menden, B., Van Evert, F., Hutchings, N., Luesink, H., Menzi, H., Misselbrook, T., Monteny, G.-J., 2008. Comparison of models used for national agricultural ammonia emission inventories in Europe: Liquid manure systems. Atmospheric Environment 42(14), 3452-3464.

Reijs, J.W., 2007. Improving slurry by diet adjustments: a novelty to reduce $\mathrm{N}$ losses from grassland based dairy farms. PhD thesis. Wageningen University, Wageningen, The Netherlands.

Rennie, T.J., Gordon, R.J., Smith, W.N., VanderZaag, A.C., 2018. Liquid manure storage temperature is affected by storage design and management practices-A modelling assessment. Agriculture, Ecosystems \& Environment 260, 47-57.

Rotz, C.A., Corson, M.S., Chianese, D.S., Montes, F., Hafner, S.D., Bonifacio, H.F., Coiner, C.U., 2016. Integrated Farm System Model: Reference Manual. Vol. 4.3. Pasture Systems and Watershed Management Research Unit, Agricultural Research Service, USDA, United States.

Sommer, S.G., 2001. Effect of composting on nutrient loss and nitrogen availability of cattle deep litter. European Journal of Agronomy 14(2), 123-133.

Sommer, S.G., Petersen, S.O., Møller, H.B., 2004. Algorithms for calculating methane and nitrous oxide emissions from manure management. Nutrient Cycling in Agroecosystems 69(2), 143-154.

Stocker, T.F., Qin, D., Plattner, G.-K., Tignor, M., Allen, S.K., Boschung, J., Nauels, A., Xia, Y., Bex, V., Midgley, P.M., 2013. Climate Change 2103: the Physical Science Basis. , 1 ed., New York, USA.

Szanto, G., Hamelers, H., Rulkens, W., Veeken, A., 2007. NH3, N2O and CH4 emissions during passively aerated composting of straw-rich pig manure. Bioresource Technology 98(14), 2659-2670. 
Vrr ten Hoeve, M., Hutchings, N.J., Peters, G.M., Svanström, M., Jensen, L.S., Bruun, S., 2014. VY Life cycle assessment of pig slurry treatment technologies for nutrient redistribution in vro Denmark. Journal of Environmental Management 132, 60-70.

Vry Tiquia, S., Richard, T., Honeyman, M., 2002. Carbon, nutrient, and mass loss during VYV composting. Nutrient Cycling in Agroecosystems 62(1), 15-24.

VY^ Tittonell, P., Rufino, M.C., Janssen, B.H., Giller, K.E., 2010. Carbon and nutrient losses YYq during manure storage under traditional and improved practices in smallholder crop-livestock vr. Systems - evidence from Kenya. Plant and Soil 328(1-2), 253-269.

VrI Torquati, B., Venanzi, S., Ciani, A., Diotallevi, F., Tamburi, V., 2014. Environmental Vrr sustainability and economic benefits of dairy farm biogas energy production: A case study in Vrr Umbria. Sustainability 6(10), 6696-6713.

Vrะ Vonk, J., Bannink, A., van Bruggen, C., Groenestein, C., Huijsmans, J., van der Kolk, J., vro Luesink, H., Voshaar, S.O., Sluis, S., Velthof, G., 2016. Methodology for estimating Vry emissions from agriculture in the Netherlands. Wageningen University \& Research, vrv Wageningen, The Netherlands.

Vr^ Whiting, A., Azapagic, A., 2014. Life cycle environmental impacts of generating electricity vrq and heat from biogas produced by anaerobic digestion. Energy 70, 181-193.

v๕. Yazan, D.M., Cafagna, D., Fraccascia, L., Mes, M., Pontrandolfo, P., Zijm, H., 2018. $V \leqslant 1$ Economic sustainability of biogas production from animal manure: a regional circular $v \leqslant r \quad$ economy model. Management Research Review 41(5), 605-624. 


\title{
1 Supporting Information
}

2

4

5

6

7

8

9

10

11

\section{Technical, environmental and cost - benefit assessment of manure management chain: case study of large scale dairy farming}

\author{
Paria Sefeedpari ${ }^{\mathrm{a}, \mathrm{b}, \mathrm{c}^{*}}$, Theun Vellinga ${ }^{\mathrm{b}}$, Shahin Rafiee ${ }^{\mathrm{a}^{*}}$, Mohammad Sharifi $^{\mathrm{a}}$, Philip Shine ${ }^{\mathrm{d}}$, \\ Seyyed Hassan Pishgar-Komleh ${ }^{\mathrm{e}}$
}

${ }^{a}$ Department of Agricultural Machinery, Faculty of Agricultural Engineering and Technology, University of Tehran, Karaj, P.O. Box 4111, Iran.

${ }^{\mathrm{b}}$ Wageningen Livestock Research, Wageningen University and Research, PO Box 338, $6700 \mathrm{AH}$, Wageningen, The Netherlands.

${ }^{\mathrm{c}}$ Institute of Soil Science and Plant Cultivation-State Research Institute, P.O. Box 24100 Puławy, Poland

${ }^{\mathrm{d}}$ Department of Process, Energy and Transport Engineering, Cork Institute of Technology, Cork, Ireland

${ }^{\mathrm{e}}$ Department of Economics, Faculty of Economics and Management, Czech University of Life Sciences Prague, Kamýcká 129, 165 00Prague, Suchdol, Czech Republic

*Corresponding author email: pariasefeedpari@ut.ac.ir

Table S1. Comparison of the most relevant studies that reported models for evaluating manure management systems

\begin{tabular}{|c|c|c|c|c|c|c|c|}
\hline Reference & $\mathrm{TE}^{1}$ & $\mathrm{EN}^{2}$ & $\mathrm{EC}^{3}$ & $\begin{array}{l}\text { Single } \\
\text { MMC }\end{array}$ & $\begin{array}{l}\text { Multiple } \\
\text { MMC }\end{array}$ & Region & Method \\
\hline Sommer et al. (2004) & $x$ & $\checkmark$ & $x$ & $x$ & $\checkmark$ & Europe & Dynamic modelling \\
\hline Schils et al. (2007) & $\checkmark$ & $\checkmark$ & $\checkmark$ & $\checkmark$ & $x$ & Netherlands & Empirical modelling \\
\hline Menind and Olt (2009) & $x$ & $x$ & $\checkmark$ & $\checkmark$ & $x$ & Estonia & Cost-benefit analysis \\
\hline Prapaspongsa et al. (2010) & $x$ & $\checkmark$ & $x$ & $x$ & $\checkmark$ & Denmark & LCA \\
\hline De Vries et al. (2012) & $x$ & $\checkmark$ & $x$ & $x$ & $\checkmark$ & Netherlands & LCA \\
\hline ten Hoeve et al. (2014) & $x$ & $\checkmark$ & $x$ & $\checkmark$ & $x$ & Denmark & LCA \\
\hline Torquati et al. (2014) & $x$ & $x$ & $\checkmark$ & $\checkmark$ & $x$ & Italy & Economic modelling \\
\hline Aguirre-Villegas et al. (2014) & $x$ & $\checkmark$ & $x$ & $x$ & $\checkmark$ & Wisconsin & Mechanistic modelling \\
\hline Hamelin et al. (2014) & $x$ & $\checkmark$ & $x$ & $\checkmark$ & $x$ & Denmark & Consequential LCA \\
\hline Pardo et al. (2017) & $x$ & $\checkmark$ & $x$ & $x$ & $\checkmark$ & Europe & Mechanistic modelling \\
\hline Makara and Kowalski (2018) & $\checkmark$ & $x$ & $x$ & $x$ & $\checkmark$ & Poland & MCDM \\
\hline Ström et al. (2018) & $\checkmark$ & $x$ & $\checkmark$ & $x$ & $\checkmark$ & Cambodia & Socio-economic analysis \\
\hline Current study & $\checkmark$ & $\checkmark$ & $\checkmark$ & $\checkmark$ & $\checkmark$ & Iran & $\begin{array}{c}\text { Process-based modelling } \\
\text { framework }\end{array}$ \\
\hline
\end{tabular}


${ }^{1}$ Technical analysis ${ }^{2}$ Environmental analysis ${ }^{3}$ Economic analysis ${ }^{4}$ Cost-benefit analysis ${ }^{5}$ Multi-Criteria decision making 21

22 2. Material and methods

23

\subsection{Manure excretion}

24 To estimate the feed intake for animal subcategories, the following equations were used

25 (IPCC, 2006).

$$
\begin{aligned}
& N E_{m}=C f_{i} \times L W^{0.75} \\
& N E_{a}=C_{a} \times N E_{m}
\end{aligned}
$$$$
N E_{g}=22.02 \times(B W / C \times M W)^{0.75} \times W G^{1.97}
$$$$
N E_{l}=\text { Milk } \times(1.47+0.40 \times M F)
$$$$
N E_{p}=C_{p} \times N E_{m}
$$$$
R E M=\left[1.123-\left(4.092 \times 10^{-3} \times D E \%\right)\right.
$$$$
\left.+\left[1.126 \times 10^{-5} \times(D E \%)^{2}\right]\right]-(25.4 / D E \%)
$$$$
R E G=\left[1.64-\left(5.160 \times 10^{-3} \times D E \%\right]+\left[1.308 \times 10^{-5} \times(D E \%)^{2}\right]\right.
$$$$
-(37.4 / D E \%)
$$$$
G E=\left[\left(N E_{m}+N E_{a}+N E_{l}+N E_{p}\right) / R E M\right]+\left(N E_{g} / R E G\right) / D E \% / 100
$$$$
26
$$

$\mathrm{NE}_{\mathrm{m}}=$ net energy required for the maintenance $\left(\mathrm{MJ} \mathrm{d}^{-1}\right)$

$\mathrm{Cf}_{\mathrm{i}}=\mathrm{a}$ coefficient corresponded to animal category $\left(\mathrm{MJ} \mathrm{d}^{-1} \mathrm{~kg}^{-1}\right.$ ) (Table S2)

$\mathrm{LW}=$ live weight of animal $(\mathrm{kg})$

$\mathrm{NE}_{\mathrm{a}}=$ net energy for animal activity (MJ $\mathrm{d}^{-1}$ )

$\mathrm{C}_{\mathrm{a}}=$ a coefficient corresponded to feeding situation (Table S2)

$\mathrm{NE}_{\mathrm{g}}=$ net energy needed for growth $(\mathrm{MJ}$ $\left.\mathrm{d}^{-1}\right)$

$\mathrm{BW}=$ the average live body weight $(\mathrm{kg})$ $\mathrm{MW}=$ the mature live body weight of, $\mathrm{kg}$

$\mathrm{WG}=$ the average daily weight gain, $\mathrm{kg}$ $\mathrm{d}^{-1}$

$\mathrm{C}=\mathrm{a}$ coefficient corresponded to the animal sex (Table S2)

$\mathrm{NE}_{\mathrm{l}}=$ net energy for lactation $\left(\mathrm{MJ} \mathrm{d}^{-1}\right)$

Milk = amount of milk produced $\left(\mathrm{kg} \mathrm{d}^{-1}\right)$ $\mathrm{MF}=$ fat content of milk $(\%)$

$\mathrm{NE}_{\mathrm{p}}=$ net energy required for pregnancy $\left(\mathrm{MJ} \mathrm{d}^{-1}\right)$

$\mathrm{C}_{\mathrm{p}}=$ pregnancy coefficient (Table S2)

$\mathrm{NE}_{\mathrm{m}}=$ net energy required for the maintenance $\left(\mathrm{MJ} \mathrm{d}^{-1}\right)$

REM= ratio of net energy in a diet for maintenance to digestible energy consumed $\mathrm{DE} \%=$ digestible energy expressed as a percentage of gross energy (Table S3)

$\mathrm{REG}=$ ratio of net energy available for growth in a diet to digestible energy consumed $\mathrm{DE} \%=$ digestible energy expressed as a percentage of gross energy

See Eqs. (S1-S7) 
Table S2. Coefficients for estimating feed (IPCC, 2006)

\begin{tabular}{lcc}
\hline $\mathrm{C}_{\mathrm{fi}}:$ Cattle/Buffalo (non-lactating cows) & $\mathrm{MJ} \mathrm{d}^{-1} \mathrm{~kg}^{-1}$ & 0.322 \\
$\mathrm{C}_{\mathrm{fi}}:$ Cattle/Buffalo (lactating cows) & $\mathrm{MJ} \mathrm{d}^{-1} \mathrm{~kg}^{-1}$ & 0.386 \\
$\mathrm{C}_{\mathrm{fi}}:$ Cattle/Buffalo (bulls) & $\mathrm{MJ} \mathrm{d}^{-1} \mathrm{~kg}^{-1}$ & 0.37 \\
$\mathrm{C}_{\mathrm{a}}:$ Ranging & $(-)$ & 0.36 \\
$\mathrm{C}_{\mathrm{a}}$ : Grazing & $(-)$ & 0.17 \\
$\mathrm{C}_{\mathrm{a}}:$ Stall & $(-)$ & 0 \\
$\mathrm{C}_{\mathrm{g}}:$ female cattle & $(-)$ & 0.8 \\
$\mathrm{C}_{\mathrm{g}}:$ castrates & $(-)$ & 1.0 \\
$\mathrm{C}_{\mathrm{g}}:$ bulls & $(-)$ & 1.2 \\
$\mathrm{C}_{\mathrm{p}}:$ Pregnancy dairy cows & $(-)$ & 0.1 \\
\hline
\end{tabular}

Table S3. Feed characteristics of the cattle farm

\begin{tabular}{lccccccc}
\hline \multirow{2}{*}{ Feed LCI- Standards } & $\mathrm{DM}$ & $\mathrm{DE}$ & $\mathrm{CP}$ & $\mathrm{GE}$ & $\mathrm{P}$ & $\mathrm{K}$ & $\mathrm{Na}$ \\
\cline { 2 - 7 } & $\mathrm{g} \mathrm{kg}^{-1}$ & $\%$ & $\mathrm{~g} \mathrm{~kg}^{-1}$ & $\mathrm{MJ} \mathrm{kg}^{-1}$ & $\mathrm{~g} \mathrm{~kg}^{-1}$ & $\mathrm{~g} \mathrm{~kg}^{-1}$ & $\mathrm{~g} \mathrm{~kg}^{-1}$ \\
\hline Standard concentrate & 894 & 80.94 & 157.72 & 16.1 & 6.89 & 10 & 0.2 \\
Maize silage & 370 & 71.9 & 186 & 19.1 & 1.7 & 10.4 & 0.1 \\
Alfalfa & 894 & 61.8 & 203.58 & 18.2 & 2.6 & 24.6 & 0.2 \\
Wheat Straw & 910 & 48.4 & 46.15 & 18.5 & 0.7 & 11.2 & 0.1 \\
Cotton meal & 922 & 81.7 & 49 & 21.2 & 12.40 & 16.60 & 0.9 \\
Molasses & 730 & 79.7 & 75.34 & 14.7 & 0.7 & 51 & 2.4 \\
Cotton seed & 923 & 62.8 & 236.18 & 23.8 & 5.9 & 12 & 0.1 \\
\hline
\end{tabular}

$\mathrm{DM}=$ Dry matter content, $\mathrm{DE}=$ Digestibility, $\mathrm{CP}$ : Crude protein, $\mathrm{GE}=$ Gross energy, $\mathrm{P}=$ phosphorus, $\mathrm{K}=$ potassium, $\mathrm{Na}=$ Sodium (Feedipedia (2017), Standard concentrate from statistical data)

29 The amount of nitrogen $(\mathrm{N})$ excreted by cattle was calculated as the difference between the total nitrogen taken in by the animal and the total nitrogen retained for milk production and

31 growth. $\mathrm{N}$ intake is calculated as follows (Eq. (S9)) (IPCC, 2006):

$N_{\text {intake }}=G E / G E_{\text {feed }} \times(C P / 6.25) / 100$

32 where,

$33 \mathrm{~N}_{\text {intake}}=$ daily $\mathrm{N}$ consumed per animal, $\mathrm{kg} \mathrm{N}$ animal ${ }^{-1} \mathrm{~d}^{-1}$ 
GE = gross energy intake of the animal, based on Eq. (S3), and IPCC (2006) constants, MJ $\operatorname{animal}^{-1} \mathrm{~d}^{-1}$

$\mathrm{GE}_{\text {feed }}=$ gross energy for dietary per $\mathrm{kg}$ of dry matter, $\mathrm{MJ} \mathrm{kg}^{-1}$, from Table S3.

$\mathrm{CP}=$ crude protein content of diet, $\mathrm{g} \mathrm{kg}^{-1}$

$6.25=$ conversion from $\mathrm{kg}$ of dietary protein to $\mathrm{kg}$ of dietary $\mathrm{N}, \mathrm{kg}$ feed protein $(\mathrm{kg} \mathrm{N})^{-1}$

The total retention of $\mathrm{N}$ is derived from the following equation (IPCC, 2006):

$N_{\text {retention }}=\left[\operatorname{Milk} \times\left(\frac{\text { MilkP\% }}{100}\right) / 6.38\right]+\left[W G \times\left[268-\left(\frac{7.03 \times N E_{g}}{W G}\right)\right] / 6.25\right]$

where,

$$
\mathrm{N}_{\text {retention }}=\text { daily } \mathrm{N} \text { retained per animal, } \mathrm{kg} \mathrm{N} \text { animal }{ }^{-1} \mathrm{~d}^{-1}
$$

Milk $=$ milk production, $\mathrm{kg}$ animal ${ }^{-1} \mathrm{~d}^{-1}$ (applicable to dairy cows only)

Milk $\mathrm{P} \%=$ percent of protein in milk (input data to the model while it can be calculated as $[1.9+0.4 *$ milk fat $\%]$, where milk fat $\%$ is an input, assumed to be $4 \%$ for cow milk.

$6.38=$ conversion from milk protein to milk $\mathrm{N}, \mathrm{kg}$ Protein $\mathrm{kg} \mathrm{N}^{-1}$

$\mathrm{WG}=$ weight gain, $\mathrm{kg} \mathrm{d}^{-1}$

268 and $7.03=$ constants, dimensionless $(\mathrm{NRC}, 2001)$

$\mathrm{NE}_{\mathrm{g}}=$ net energy for growth, calculated from Eq. (S3), MJ d $\mathrm{d}^{-1}$

Phosphorous $(\mathrm{P})$ and Potassium $(\mathrm{K})$ retention in milk and tissue are estimated using the following coefficients in Table S4.

Table S4. P and K retention in milk and tissue of cattle (WUM, 2009)

\begin{tabular}{lccc}
\hline & Weight & $\mathrm{P}$ & $\mathrm{K}$ \\
Milk & & 1 & 1.6 \\
Growth & 600 & 7.4 & 2 \\
\hline
\end{tabular}

Once gross energy (GE) intake and its fractional digestibility are estimated, the VS excretion rate is estimated as (IPCC, 2006):

$V S=\left[G E_{\text {feed }} \times\left(1-\frac{D E \%}{100}\right)+(U E \times G E)\right] \times\left[\left(\frac{1-A S H}{18.45}\right)\right]$ 
where,

$54 \mathrm{VS}=$ volatile solid excretion $\mathrm{d}^{-1}$ on a dry-organic matter basis, $\mathrm{kg} \mathrm{VS}$ animal ${ }^{-1} \mathrm{~d}^{-1}$

$55 \quad \mathrm{GE}_{\text {feed }}=$ gross energy intake, $\mathrm{MJ} \mathrm{d}^{-1}$

$56 \mathrm{DE} \%=$ digestibility of the feed in percent (e.g. 60\%)

$57 \mathrm{UE}=$ urinary energy as fraction of GE (assumed to be $0.04 * \mathrm{GE}$ for most ruminant while as

58 the amount of grain in diet increases, this fraction reduces to 0.02)

$59 \mathrm{GE}_{\text {feed }}=$ gross energy for dietary per $\mathrm{kg}$ of dry matter, $\mathrm{MJ} \mathrm{kg}^{-1}$ (Table S3)

$60 \mathrm{ASH}=$ ash content of manure (assumed to be 0.08 for cattle)

61 From Sommer et al. (2004), the degradable and non-degradable volatile solids $\left(\mathrm{VS}_{\mathrm{d}}\right.$ and

$62 \quad \mathrm{VS}_{\mathrm{nd}}$ ) are calculated as:

$V S_{d}=V S \frac{E_{C H 4 a c t}}{E_{C H 4 p o t}}$

63 where,

$64 \mathrm{VS}=$ total VS in the manure $(\mathrm{g})$,

$65 \mathrm{E}_{\mathrm{CH} 4 \mathrm{act}}=$ achievable emission of $\mathrm{CH}_{4}$ during anaerobic digestion $\left(\mathrm{g} \mathrm{kg}^{-1} \mathrm{VS}\right)($ Table S5)

$66 \mathrm{E}_{\mathrm{CH} 4 \mathrm{pot}}=$ potential $\mathrm{CH}_{4}$ yield of the manure $\left(\mathrm{g} \mathrm{kg}^{-1} \mathrm{VS}\right)($ Table S5)

Table S5. Parameters and coefficients for manure characteristics

\begin{tabular}{lccc}
\hline Urinary energy & $\%$ of GE & $2-4$ & (IPCC, 2006) \\
Ash content & $\%$ & 8 & (IPCC, 2006) \\
Volatile solids content $^{1}$ & $\mathrm{~g} \mathrm{VS} \mathrm{g} \mathrm{TS}^{-1}$ & $0.68,0.698,0.726$ & (Rotz et al., 2016) \\
Actual $\mathrm{CH}_{4}$ & $\mathrm{~g} \mathrm{CH}_{4} \mathrm{~kg}^{-1} \mathrm{VS}$ & 0.2 & (Sommer et al., 2004) \\
Potential CH & $\mathrm{g} \mathrm{CH}_{4} \mathrm{~kg}^{-1} \mathrm{VS}$ & 0.48 & (Sommer et al., 2004) \\
Carbon content & $\%$ of OM & 45.37 & (Bianchi et al., 2008) \\
\hline
\end{tabular}

${ }^{1}$ Values for lactating cows, dry cows, heifers

67 Non-degradable VS is calculated as follows (Aguirre-Villegas et al., 2014):

$V S_{n d}=V S-V S_{d}$

TAN is calculated by the following equations (Vonk et al., 2016): 
$N_{\text {dung }}=N_{\text {tot }} *(100-D E) / 100$

$N_{\text {Urine }}=N_{\text {tot }}-N_{\text {dung }}$

$\operatorname{TAN}\left(N_{\text {urine }}\right)=\left(N_{\text {tot }}-N_{\text {dung }}\right)+\left(N_{\text {mineralization }} * N_{\text {tot }}\right)$

$N_{\text {org }}=N_{\text {dung }}-\left(N_{\text {mineralization }} * N_{\text {tot }}\right)$

69 where,

$70 \quad \mathrm{~N}_{\text {dung }}=$ total nitrogen excreted in dung $\left(\mathrm{kg} \mathrm{farm}^{-1} \mathrm{~d}^{-1}\right)$

$71 \quad \mathrm{~N}_{\text {tot }}=$ total nitrogen excretion $\left(\mathrm{kg} \mathrm{farm}^{-1} \mathrm{~d}^{-1}\right)$

72 TAN $=$ total ammoniacal nitrogen $\left(\mathrm{kg} \mathrm{farm}^{-1} \mathrm{~d}^{-1}\right)$

$73 \mathrm{~N}_{\text {mineralization }}=$ percentage of mineralization of organic $\mathrm{N}$ in manure $(\%),\left(10 \%\right.$ of $\mathrm{N}_{\text {org }}$ during

74 liquid storage and in the animal house (Beline et al., 1998; Vonk et al., 2016).

75

76

77

\subsection{Description of process-based analysis}

\subsubsection{Collection and housing}

Table S6 lists approximate bedding requirements for a cow of $680 \mathrm{~kg}$ of body weight.

Table S6. Bedding volume for $680 \mathrm{~kg}$ of BW

\begin{tabular}{lccc}
\hline Manure solids & $\mathrm{kg} \mathrm{d}^{-1}$ & 1.395 & (Lorimor et al., 2004) \\
Sand & $\mathrm{kg} \mathrm{d}^{-1}$ & 20 & (Gooch et al., 2003) \\
Organic & $\mathrm{kg} \mathrm{d}^{-1}$ & 1.395 & (Lorimor et al., 2004) \\
Straw & $\mathrm{kg} \mathrm{d}^{-1}$ & 2 & (Lorimor et al., 2004) \\
Chopped bedding & $\mathrm{kg} \mathrm{d}^{-1}$ & 1.8 & (Lorimor et al., 2004) \\
\hline
\end{tabular}

Generally, the average fuel consumption of a tractor is calculated using the following formula

79 (Grisso et al., 2004). The same approach was used for fuel consumption during manure 80 collection.

$$
Q_{\text {avg }}=0.223 \times P_{p t o}
$$

81 where,

$82 \mathrm{Q}_{\text {avg }}=$ average gasoline consumption, $\mathrm{L} \mathrm{h}^{-1}$

$83 \quad \mathrm{P}_{\mathrm{pto}}=$ maximum PTO power, $\mathrm{kW}$

84 The $\mathrm{CO}_{2}$ emission factor of diesel was considered to be $3.17 \mathrm{~kg} \mathrm{CO}_{2 \mathrm{eq}} \mathrm{MJ}^{-1}$ (Daneshi et al., 2014). 
$N H_{3 \text { emission in housing }}=\left(T A N+N_{\text {org }} \times N_{\text {mineralization }}\right) \times N_{\text {tot }} \times$ housing share $\times$ EF $\mathrm{NH}_{3} \times 17 / 14$

86

$87 \mathrm{NH}_{3}$ emission in housing $=$ ammonia emission $\left(\mathrm{kg} \mathrm{NH}_{3} \mathrm{~d}^{-1}\right)$

88

89

90

91

92

$$
\begin{aligned}
& \mathrm{N}_{2} \mathrm{O}_{\text {emissions }}=\left(\mathrm{N}_{2} \mathrm{O}_{\text {direct }+} \mathrm{N}_{2} \mathrm{O}_{\text {indirect }}\right) \times 44 / 28 \\
& \mathrm{~N}_{2} \mathrm{O}_{\text {emissions }}=N_{\text {tot }} \times E F \mathrm{~N}_{2} \mathrm{O} \times 44 / 28
\end{aligned}
$$

93 where,

$94 \quad \mathrm{~N}_{2} \mathrm{O}_{\text {emissions }}=$ nitrous oxide emissions $\left(\mathrm{kg} \mathrm{N}_{2} \mathrm{O} \mathrm{d}^{-1}\right)$

$\mathrm{N}_{2} \mathrm{O}-\mathrm{N}_{\text {direct }}=$ direct nitrous oxide emission $\left(\mathrm{kg} \mathrm{N}_{2} \mathrm{O}-\mathrm{N} \mathrm{d}^{-1}\right)$ from manure management process,

$\mathrm{N}_{2} \mathrm{O}-\mathrm{N}_{\text {indirect }}=$ indirect nitrous oxide emission $\left(\mathrm{kg} \mathrm{N}_{2} \mathrm{O}-\mathrm{N} \mathrm{d} \mathrm{d}^{-1}\right)$ following atmospheric

97 deposition of $\mathrm{NH}_{3}$ and $\mathrm{NO}_{\mathrm{x}}$ from manure management

$98 \quad \mathrm{~N}_{\text {tot }}=$ the total $\mathrm{N}$ of manure $\left(\mathrm{kg} \mathrm{N}\right.$ farm $\left.\mathrm{d}^{-1}\right)$

EF $\mathrm{N}_{2} \mathrm{O}=$ the emission factor adapted from IPCC (2006) $\left(\mathrm{kg} \mathrm{N}_{2} \mathrm{O} \mathrm{kg} \mathrm{N} \mathrm{kg}^{-1}\right)$

$44 / 28=$ conversion factor from $\mathrm{N}_{2} \mathrm{O}-\mathrm{N}$ to $\mathrm{N}_{2} \mathrm{O}$.

Direct $\mathrm{N}_{2} \mathrm{O}$ emissions from livestock manure are calculated as follows (Vonk et al., 2016):

$\mathrm{N}_{2} \mathrm{O}-\mathrm{N}_{\text {emissions-direct }}=\mathrm{N}_{\text {tot }} \times E F \mathrm{~N}_{2} \mathrm{O}_{\text {direct }} \times M M S$ share

102

where,

103

$\mathrm{N}_{2} \mathrm{O}_{\text {emission-direct }}=$ direct nitrous oxide emission $\left(\mathrm{kg} \mathrm{N}_{2} \mathrm{O}-\mathrm{N}\right.$ farm $\left.{ }^{-1} \mathrm{~d}^{-1}\right)$

104

$\mathrm{N}_{\text {tot }}=$ total nitrogen $\left(\mathrm{kg} \mathrm{N}\right.$ farm $\left.{ }^{-1} \mathrm{~d}^{-1}\right)$

105

$\mathrm{EF} \mathrm{N}_{2} \mathrm{O}$ direct $=$ emission factor for manure management system in $\mathrm{kg} \mathrm{N}_{2} \mathrm{O}-\mathrm{N} \mathrm{kg} \mathrm{N}^{-1}$ influent 
107 To estimate indirect nitrous oxide emission, the sum of total $\mathrm{NH}_{3}$ and $\mathrm{NO}_{\mathrm{x}}$ emissions from

108 manure management process are multiplied with an emission factor (Vonk et al., 2016).

$\mathrm{N}_{2} \mathrm{O}_{\text {emission-indirect }}=\left(\mathrm{NH}_{3} \times 14 / 17+\mathrm{NO}_{\mathrm{x}} \times 14 / 30\right) \times \mathrm{EF} \mathrm{N}_{2} \mathrm{O}$ indirect

109 where,

$110 \mathrm{~N}_{2} \mathrm{O}_{\text {emission-indirect }}=$ indirect nitrous oxide emission $\left(\mathrm{kg} \mathrm{N}_{2} \mathrm{O}-\mathrm{N}\right.$ farm $\left.{ }^{-1} \mathrm{~d}^{-1}\right)$ due to atmospheric deposition of $\mathrm{NH}_{3}$ and $\mathrm{NO}_{\mathrm{x}}$ within all manure management system

$112 \mathrm{NH}_{3}=$ ammonia emission $\left(\mathrm{kg} \mathrm{NH}_{3}\right.$ farm $\left.^{-1} \mathrm{~d}^{-1}\right)$ within all defined MMS

$113 \quad 14 / 17=$ conversion factor from $\mathrm{NH}_{3}$ to $\mathrm{NH}_{3}-\mathrm{N}$

$114 \mathrm{NO}_{\mathrm{x}}=$ nitrogen monoxide emissions $\left(\mathrm{kg} \mathrm{NO}_{\mathrm{x}}\right)$ within all defined MMS

$11514 / 30=$ conversion factor from $\mathrm{NO}_{\mathrm{x}}$ (expressed as nitrogen monoxide) to $\mathrm{NO}_{\mathrm{x}}-\mathrm{N}$

$116 \mathrm{EF} \mathrm{N}_{2} \mathrm{O}_{\text {indirect }}=$ emission factor for indirect emission in $\mathrm{N}_{2} \mathrm{O}-\mathrm{N} \mathrm{kg} \mathrm{N} \mathrm{N}^{-1}$ emitted as $\mathrm{NH}_{3}$ and $117 \quad \mathrm{NO}_{\mathrm{x}}$

Table S7. Emission factors of $\mathrm{N}_{2} \mathrm{O}, \mathrm{NO}_{\mathrm{x}}, \mathrm{N}_{2}$ and $\mathrm{NH}_{3}$ in different housing systems $\left(\mathrm{kg} \mathrm{kg}^{-1} \mathrm{~N}_{\text {tot }}\right)$ (IPCC, 2006)

\begin{tabular}{lccccc}
\hline \multirow{2}{*}{ Loose housing } & $\mathrm{NO}_{\mathrm{x}}-\mathrm{N}$ & $\mathrm{N}_{2}-\mathrm{N}$ & $\mathrm{N}_{2} \mathrm{O}-\mathrm{N}_{\text {direct }}$ & $\begin{array}{c}\mathrm{N}_{2} \mathrm{O}-\mathrm{N}_{\text {indirect }} \text { (per kg } \\
\left.\mathrm{N} \text { as } \mathrm{NH}_{3} \text { and } \mathrm{NO}_{\mathrm{x}}\right)\end{array}$ & $\mathrm{NH}_{3}$ (\% TAN) \\
\cline { 2 - 6 } & 0.005 & 0.025 & 0.02 & & \\
\hline Liquid & & & & \\
Solid & 0.002 & 0.02 & 0.002 & 0.01 & \\
\hline
\end{tabular}

For slurry stream an average is taken.

118 From Chianese et al. (2009), an empirical equation for estimating $\mathrm{CH}_{4}$ emission to the 119 ambient temperature $\left(\mathrm{R}^{2}=0.48\right)$ was used to calculate $\mathrm{CH}_{4}$ emission in free stalls (Eq. (S24)):

$E C H_{4 \text { floor-free stall }}=\max (0,0.13 * T) * \frac{A_{\text {barn }}}{1000}$

120 where,

$121 \mathrm{E}_{\mathrm{CH} 4 \text { freestall floor }}=$ daily rate of $\mathrm{CH}_{4}$ emissions from barn $\left(\mathrm{kg} \mathrm{CH}_{4} \mathrm{~d}^{-1}\right)$ 
$122 \mathrm{~T}=$ ambient temperature $\left({ }^{\circ} \mathrm{C}\right)$

$123 \quad \mathrm{~A}_{\text {barn }}=$ floor area exposed to manure $\left(\mathrm{m}^{2}\right)$

124 Following equation was utilized to estimate $\mathrm{CH}_{4}$ emissions in loose housing system (IPCC, 125 2006).

$\mathrm{ECH}_{\text {floor-loose housing }}=\operatorname{VS}\left(B_{o}\right)(0.67) M C F$

126 where,

$127 \mathrm{ECH}_{4}$ floor-loose hosing $=$ daily $\mathrm{CH}_{4}$ emission, $\mathrm{kg} \mathrm{CH}_{4} \mathrm{~d}^{-1}$

$128 \mathrm{VS}=$ volatile solids excreted in manure, $\mathrm{kg} \mathrm{VS}$

$129 \mathrm{~B}_{\mathrm{o}}=$ maximum $\mathrm{CH}_{4}$ producing capacity for dairy manure, $0.24 \mathrm{~m}^{3} \mathrm{CH}_{4}(\mathrm{~kg} \mathrm{VS})^{-1}$

$130 \quad 0.67=$ density of $\mathrm{CH}_{4}($ Table S11)

$131 \mathrm{MCF}=\mathrm{CH}_{4}$ conversion factor for the manure management system, \% (MCF is limited to a 132 minimum value of 0 ). In the following, the MCF is modeled as a linear relationship with 133 ambient outdoor temperature in a loose housing system.

$M C F=0.0625 T_{a}-0.25$

134 where,

$135 \mathrm{~T}_{\mathrm{a}}=$ ambient temperature, ${ }^{\circ} \mathrm{C}$

136 Emission of particulate matter production is calculated as follows:

$P M_{\text {emission }}=E F_{P M 2.5 / 10} \times$ housing share $\times$ No. of animals $/ 1000 \times 365$

137 where,

$138 \mathrm{PM}_{\text {emission }}=$ Particulate matter emission $\left(\mathrm{kg} \mathrm{PM} \mathrm{y}^{-1}\right)$

$139 \mathrm{EF}_{\mathrm{PM}} 2.5 / 10=$ Particulate matter emission factor of housing system and animal category, $\mathrm{kg}$

$140 \quad$ PM animal ${ }^{-1} \mathrm{~d}^{-1}$

$141 \quad 1000=$ conversion factor from gram to kilogram

$142365=$ conversion factor from year to day 
Table S8. Emission factors (EF) of particular matter 2.5 and 10 (Vonk et al., 2016)

\begin{tabular}{lccc}
\hline Housing type & Lactating cow & Dry cow & Heifer \\
\hline Free \& tie stall & 80.8 & 80.8 & 0 \\
10 & 22.3 & 22.3 & 0 \\
2.5 & & & \\
Traditional & 147.5 & 147.5 & 37.7 \\
10 & 40.6 & 40.6 & 10.4 \\
2.5 & & & \\
\hline
\end{tabular}

Table S9. Electric grid data (Anonymous, 2011)

\begin{tabular}{lc}
\hline Electric grid fuels mix & Electricity delivered (\%) \\
\hline Steam & 31 \\
Natural gas & 26.9 \\
Combined cycle & 36 \\
Hydro & 5 \\
Diesel/ wind/ renewable sources & 0.1 \\
Nuclear & 1.1 \\
\hline
\end{tabular}

Table S10. Assumptions and input data to AD module

CAPg - CHP size-electric capacity

CHP size- heat capacity

Electricity use of AD

CH4 leakage from installation

$\mathrm{CH} 4$ leakage from CHP

LHV of methane-mass

$E_{g}$ - Electricity conversion efficiency

Heat conversion efficiency

Specific energy of diesel

$E_{\mathrm{vs}}$ - Conversion efficiency of digester

Methane productivity

$\mathrm{CH}_{4}$ yield in $\mathrm{AD}$

$\mathrm{CO}_{2}$ yield in $\mathrm{AD}$

$\mathrm{F}_{\text {run }}$ - CHP running time

Specific heat capacity of manure

Mesophilic Temperature

\begin{tabular}{|c|c|c|}
\hline $\mathrm{kW}_{\mathrm{el}}$ & 999 & Assumed $^{1}$ \\
\hline $\mathrm{Kw}_{\text {th }}$ & 1050 & Assumed \\
\hline$\%$ of $\mathrm{m}^{3}$ influent & 6 & (FNR, 2006; Frey et al., 2013) \\
\hline$\%$ of biogas & 1 & (Hou, 2016; Pardo et al., 2017) \\
\hline$\%$ of biogas & 1.5 & (Hou, 2016; Pardo et al., 2017) \\
\hline MJ $\mathrm{kg}^{-1}$ & 50 & (Masters, 2013) \\
\hline$\%$ & 38 & (Lansche and Müller, 2012) \\
\hline$\%$ & 46 & (Lansche and Müller, 2012) \\
\hline MJ kg-1 & 45.6 & (Anonymous, 2017) \\
\hline$\%$ & 35 & (Møller et al., 2004) \\
\hline $\mathrm{kg} \mathrm{CH}_{4} \mathrm{~kg}^{-1} \mathrm{VS}$ & 0.35 & (Hill, 1984; Møller et al., 2004) \\
\hline$\%$ & 65 & (Jørgensen, 2009) \\
\hline$\%$ & 35 & (Jørgensen, 2009) \\
\hline$\%$ & 85 & Assumed \\
\hline $\mathrm{KJ} \mathrm{Kg}^{-1}{ }^{\circ} \mathrm{C}^{-1}$ & 2.8 & (Nayyeri et al., 2009) \\
\hline${ }^{\circ} \mathrm{C}$ & 38 & (Yu et al., 2014) \\
\hline
\end{tabular}


${ }^{1}$ Assumed for the modeled large scale biogas plant.

145 The power available in biogas is calculated as follows:

$$
P_{b g}=E_{C H 4}(1-\alpha)(C H 4) /(3.6 \times 100)
$$

146 where,

$147 \mathrm{P}_{\mathrm{bg}}=$ power available in the biogas produced, $\mathrm{kWh} \mathrm{d}^{-1}$

$148 \mathrm{E}_{\mathrm{CH} 4}=$ lower heating value of methane, $\mathrm{MJ} \mathrm{kg}^{-1}$ (Table S10)

$149 \alpha=$ biogas leakage rate, $\%$

$150 \mathrm{CH}_{4}=$ methane production rate, $\mathrm{kg} \mathrm{d}^{-1}$ (flow rate of volatile solids into digester $\left(\mathrm{kg} \mathrm{d}^{-1}\right) \times$ Methane 151 productivity $\times$ Conversion efficiency of digester) (Table S10)

153 The amount of biogas that can be converted to electricity is a function of operating time,

154 efficiency of the CHP generator and is formulated as follows (Rotz et al., 2016):

$E L E C T=\min \left(24 \times F_{\text {run }} \times C A P_{g}, E_{g} \times P_{b g} / 100\right)$

155 where,

156 ELECT = electricity produced, $\mathrm{kW} \mathrm{h} \mathrm{d}^{-1}$

$157 \quad \mathrm{~F}_{\text {run }}=$ portion of time engine-generator sets are running, \% (Table S10)

$158 \mathrm{CAP}_{\mathrm{g}}=$ electric generation capacity, $\mathrm{kW}($ Table $\mathrm{S} 10)$

$159 \quad \mathrm{E}_{\mathrm{g}}=$ efficiency of electric generation, \% (Table S10)

160 The heat demand of digester can be calculated considering that the temperature difference of ambient temperature and the digester (different values for summer and winter season):

$Q=m C \Delta T$

162 where,

$\mathrm{Q}=$ heat requirements, $\mathrm{kJ}$ 
$\mathrm{m}=$ manure mass, $\mathrm{kg}$

$165 \mathrm{C}=$ specific heat capacity of manure, $\mathrm{KJ} \mathrm{Kg}^{-1}{ }^{\circ} \mathrm{C}^{-1}$

$166 \Delta \mathrm{T}=$ temperature change (ambient temperature - digester temperature in ${ }^{\circ} \mathrm{C}$ )

167 The dry matter of AD effluent is calculated as follows (Rotz et al., 2016):

$Q_{e}=Q_{m}-E_{v s} Q_{v s}$

168 where,

$169 \mathrm{Q}_{\mathrm{e}}=$ digester effluent dry matter entering long term storage, $\mathrm{kg} \mathrm{d}^{-1}$

170

$Q_{m}=$ loading rate of manure dry matter, $\mathrm{kg} \mathrm{d}^{-1}$

171

$Q_{v s}=$ flow rate of volatile solids into digester, $\mathrm{kg} \mathrm{d}^{-1}$

172

$\mathrm{E}_{\mathrm{vs}}=$ efficiency of volatile solids conversion, \% (Table S10)

Table S11. Density values used in the model

\begin{tabular}{lll}
\hline Density of diesel & $\mathrm{kg} \mathrm{L}^{-1}$ & 0.83 \\
Density of manure & $\mathrm{kg} \mathrm{m}^{-3}$ & 1000 \\
Density of $\mathrm{CH}_{4}$ & $\mathrm{~kg} \mathrm{~m}^{-3}$ & 0.67 \\
Density of biogas & $\mathrm{kg} \mathrm{m}^{-3}$ & 1.15 \\
Density of $\mathrm{CO}_{2}$ & $\mathrm{~kg} \mathrm{~m}^{-3}$ & 1.98 \\
\hline
\end{tabular}

173

Then, the degradable fraction of the effluent (the volatile solids leaving the digester) is

174 determined as the difference between the VS entering and the VS decomposed in the 175 digesters:

$V S_{d}=\left(B_{o} / E C H 4_{p o t}-E_{v s}\right) Q_{v s}$

176 where,

$177 \quad \mathrm{VS}_{\mathrm{d}}=$ degradable volatile solids in effluent, $\mathrm{kg} \mathrm{d}^{-1}$

$178 \mathrm{~B}_{\mathrm{o}}=$ actual methane productivity during anaerobic digestion, $\mathrm{g}(\mathrm{kg} \mathrm{VS})^{-1}$ (Table S5)

$179 \mathrm{ECH}_{4 \text { pot }}=$ potential methane productivity during storage of the manure, $\mathrm{g}(\mathrm{kg} \mathrm{VS})^{-1}($ Table 180 S5)

181 Accordingly, the non-degradable fraction in the effluent is as follows: 
$V S_{n d}=\left(1-B_{o} / E C H_{4 p o t}\right) Q_{v s}$

where,

$183 \mathrm{VS}_{\mathrm{nd}}=$ non-degradable volatile solids in effluent, $\mathrm{kg} \mathrm{d}^{-1}$

184 Water requirement of digester is calculated as follows:

Total influent $(\mathrm{kg} / \mathrm{d})=$ Total solids of fresh discharge $(\mathrm{kg} / \mathrm{d}) \times 100 / 8$

Required water $(\mathrm{kg} /$ day $)=$ Total influent $(\mathrm{kg} /$ day $)$-Total solids of fresh discharge $(\mathrm{kg} / \mathrm{d})$

\subsubsection{Composting}

Table S12. Differences in physical and nutrient content changes during composting of manure

\begin{tabular}{lccccccccc}
\hline Composting method & $\begin{array}{c}\mathrm{DM}^{\mathrm{a}} \\
(\%)\end{array}$ & $\begin{array}{c}\mathrm{N}_{\text {tot }}{ }^{\mathrm{b}} \\
(\%)\end{array}$ & $\begin{array}{c}\mathrm{TAN}^{\mathrm{c}} \\
(\%)\end{array}$ & $\begin{array}{c}\mathrm{N}^{\mathrm{c}} \\
(\%)\end{array}$ & $\begin{array}{c}\mathrm{P}^{\mathrm{d}} \\
(\%)\end{array}$ & $\begin{array}{c}\mathrm{K}^{\mathrm{e}} \\
(\%)\end{array}$ & $\begin{array}{c}\mathrm{C}^{\mathrm{f}} \\
(\%)\end{array}$ & $\begin{array}{c}\mathrm{NH}_{3}{ }^{\mathrm{c}} \\
(\%)\end{array}$ & $\begin{array}{c}\mathrm{N}_{2} \mathrm{O} \\
\left(\mathrm{kg} \mathrm{N}_{2} \mathrm{O} \mathrm{kg}{ }^{-1} \mathrm{~N}-\text { tot }\right)^{\mathrm{g}}\end{array}$ \\
\hline In vessel & 34 & 15 & 65 & 2.6 & 1.7 & 8.2 & 40 & 16.7 & 0.006 \\
Static pile & 38 & 18 & 70 & 2.3 & 1.8 & 11.2 & 40 & 14.9 & 0.6 \\
Intensive windrow & 41 & 11.6 & 67 & 2.9 & 2.4 & 15.5 & 44 & 7.2 & 0.1 \\
Passive windrow & 45 & 28 & 70 & 3.4 & 1.7 & 13.8 & 48.5 & 12 & 0.001
\end{tabular}

${ }^{a}$ Sommer (2001); Eghball et al. (1997)

${ }^{\mathrm{b}}$ Eghball et al. (1997); Michel Jr et al. (2004); Sommer (2001)

${ }^{\mathrm{c}}$ Gibbs et al. (2002); Michel Jr et al. (2004); Sommer (2001)

${ }^{\mathrm{d}}$ Michel Jr et al. (2004); Sommer (2001)

${ }^{\mathrm{e}}$ Eghball et al. (1997); Parkinson et al. (2004); Sommer (2001)

${ }^{\mathrm{f}}$ Michel Jr et al. (2004); Sommer (2001)

${ }^{\mathrm{g}} \mathrm{IPCC}(2006)$

186

Table S13. $\mathrm{CH}_{4}$ conversion factors during different methods of composting (\%) (IPCC, 2006)

\begin{tabular}{lccccccccccccccc}
\hline Annual Ave. temperature & $<14$ & 15 & 16 & 17 & 18 & 19 & 20 & 21 & 22 & 23 & 24 & 25 & 26 & 27 & 28 \\
\hline In vessel & 0.5 & 0.5 & 0.5 & 0.5 & 0.5 & 0.5 & 0.5 & 0.5 & 0.5 & 0.5 & 0.5 & 0.5 & 0.5 & 0.5 & 0.5 \\
static pile & 0.5 & 0.5 & 0.5 & 0.5 & 0.5 & 0.5 & 0.5 & 0.5 & 0.5 & 0.5 & 0.5 & 0.5 & 0.5 & 0.5 & 0.5 \\
Intensive windrow & 0.5 & 1 & 1 & 1 & 1 & 1 & 1 & 1 & 1 & 1 & 1 & 1 & 1.5 & 1.5 & 1.5 \\
Passive windrow & 0.5 & 1 & 1 & 1 & 1 & 1 & 1 & 1 & 1 & 1 & 1 & 1 & 1.5 & 1.5 & 1.5 \\
\hline
\end{tabular}




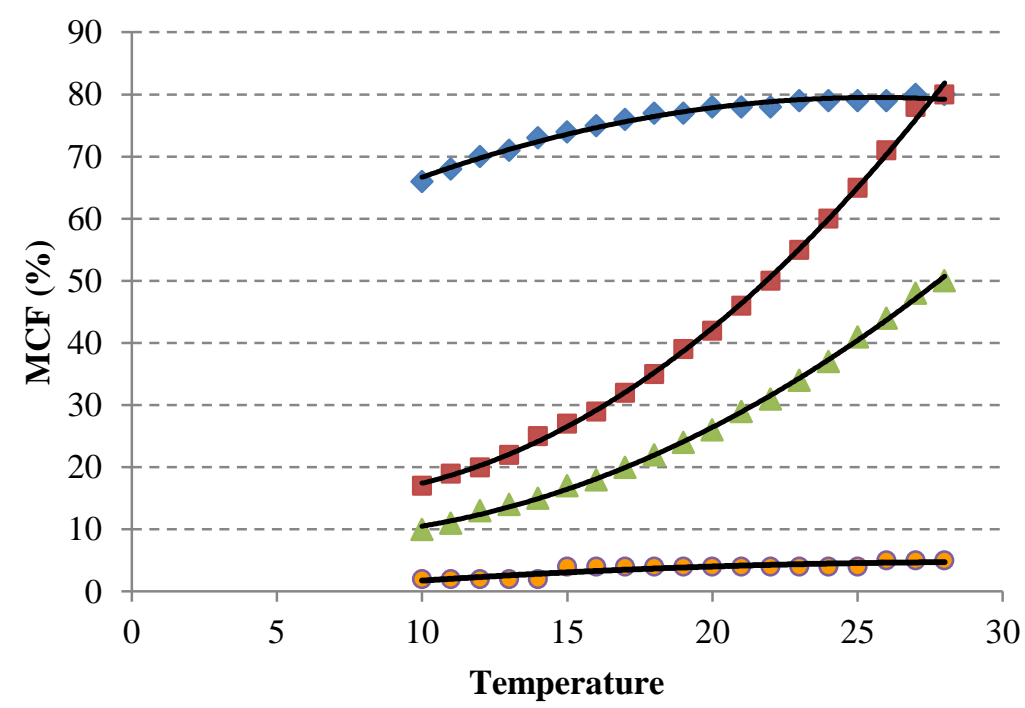



Pit-cover

$y=0.1351 x^{2}-1.5573 x+19.494$ $R^{2}=0.9987$

$\triangle \mathrm{Pit}+\mathrm{cover}$ $y=0.0803 x^{2}-0.8181 x+10.655$ $R^{2}=0.9988$

Solid storage $y=-0.0078 x^{2}+0.4618 x-2.0881$ $\mathrm{R}^{2}=0.7997$

Fig. S1. $\mathrm{CH}_{4}$ conversion factors during different methods of storage (\%)

188

Table S14. Changes to physical quality and nutrient content of manure for different storage types (\%)

\begin{tabular}{|c|c|c|c|c|c|c|c|c|c|c|c|c|c|c|c|}
\hline \multirow[b]{2}{*}{$\begin{array}{l}\text { Difference } \\
\text { to initial }\end{array}$} & \multicolumn{5}{|c|}{$<2$ mon } & \multicolumn{5}{|c|}{$2-4$ mon } & \multicolumn{5}{|c|}{$>4$ mon } \\
\hline & 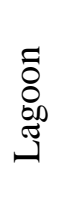 & 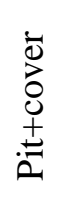 & 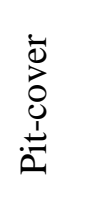 & 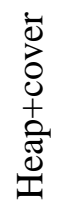 & 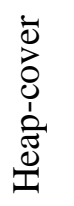 & 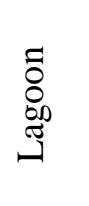 & $\begin{array}{l}\dot{\bar{D}} \\
\dot{0} \\
\dot{0} \\
\dot{ \pm}\end{array}$ & $\begin{array}{l}\dot{\bar{D}} \\
\dot{0} \\
\dot{0} \\
\dot{D}\end{array}$ &  & 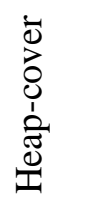 & 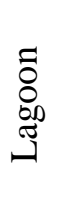 & 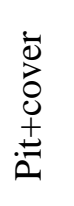 & 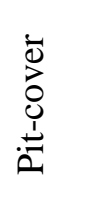 & 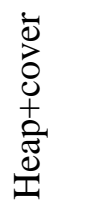 &  \\
\hline VS & 5 & 5 & 5 & 5 & 5 & 5 & 5 & 5 & 5 & 5 & 5 & 5 & 5 & 5 & 5 \\
\hline $\mathrm{TS}$ & 120 & 120 & 120 & 120 & 120 & 120 & 120 & 120 & 120 & 120 & 120 & 120 & 120 & 120 & 120 \\
\hline $\mathrm{N}$-tot & 50 & 95 & 80 & 85 & 75 & 25 & 92.5 & 72.5 & 75 & 65 & 30 & 90 & 65 & 65 & 55 \\
\hline N-min & 80 & 70 & 80 & 50 & 70 & 70 & 60 & 80 & 60 & 70 & 70 & 60 & 70 & 70 & 85 \\
\hline $\mathrm{P}$ & 65 & 20 & 50 & 35 & 40 & 75 & 30 & 60 & 45 & 50 & 60 & 50 & 50 & 60 & 60 \\
\hline K & 60 & 60 & 60 & 50 & 50 & 60 & 60 & 60 & 50 & 50 & 60 & 80 & 70 & 50 & 70 \\
\hline $\mathrm{C}$ & 60 & 50 & 55 & 25 & 30 & 70 & 60 & 65 & 35 & 40 & 70 & 65 & 70 & 85 & 70 \\
\hline
\end{tabular}

Chadwick (2005); Rotz (2004); Tittonell et al. (2010) 
Table S15. Emission factors (EF) and correction factors (CF) for different storage conditions

\begin{tabular}{lccccccccc}
\hline \multirow{2}{*}{ Factors } & \multicolumn{4}{c}{ EF } & \multicolumn{3}{c}{ CF of storage type } & \multicolumn{3}{c}{ CF of storage time (month) ${ }^{\mathrm{e}}$} \\
\cline { 2 - 10 } & $\%$ NH4-N & Lagoon $^{\mathrm{b}}$ & $\mathrm{P}^{-\mathrm{C}^{*}}$ & $\mathrm{P}+\mathrm{C}^{* \mathrm{c}}$ & $\mathrm{H}-\mathrm{C}^{* \mathrm{~b}}$ & $\mathrm{H}+\mathrm{C}^{*}$ & $<2$ & $2-4$ & $>4$ \\
\hline $\mathrm{NH}_{3}-\mathrm{N}$ & $0.15^{\mathrm{a}}$ & 3 & 1 & 0.5 & 0.2 & 0 & 0.5 & 0.8 & 1 \\
$\mathrm{~N}_{2} \mathrm{O}-\mathrm{N}$ & $0.01^{\mathrm{d}}$ & 0.1 & 0.1 & 2 & $2^{\mathrm{e}}$ & 0 & 0.5 & 0.8 & 1 \\
\hline
\end{tabular}

${ }^{*} \mathrm{P}-\mathrm{C}=$ Pit-cover, $\mathrm{P}+\mathrm{C}=$ Pit+cover, $\mathrm{H}-\mathrm{C}=$ Heap- cover, $\mathrm{H}+\mathrm{C}=$ Heap+ cover

${ }^{a}$ Clemens et al. (2006); Misselbrook et al. (2015); Rotz (2004)

${ }^{\mathrm{b}}$ Misselbrook et al. (2015); Pardo et al. (2017); Rotz (2004)

${ }^{\mathrm{c}}$ Amon et al. (2006); Pardo et al. (2017)

${ }^{\mathrm{d}}$ Clemens et al. (2006); Pardo et al. (2017)

${ }^{\text {e }}$ Petersen et al. (1998)

191

Table S16. Parameters for manure treatment processes

\begin{tabular}{lccc}
\hline Parameter & Unit & Value & Reference \\
\hline sand recovery efficiency & $\%$ & 87 & (Wedel, 2012) \\
sand recovery efficiency for AD & $\%$ & 95 & (Wedel, 2012) \\
Sand Sep. electricity use- 87\% & $\mathrm{kWh} \mathrm{m}^{-3}$ & 0.15 & (Wedel, 2012) \\
Sand Sep. electricity use- 95\% & $\mathrm{kWh} \mathrm{m}^{-3}$ & 0.26 & (Wedel, 2012) \\
Emission factor of electricity & $\mathrm{CO}_{2-\mathrm{eq}} \mathrm{kWh}^{-1}$ & 0.91 & $(3.3,2016)$ \\
$\mathrm{N}$ mineralization in AD & $\%$ & 43 & (Jørgensen, 2009) \\
P loss in AD & $\%$ & 0 & (Bachmann et al., 2011; Möller and Stinner, \\
K loss in AD & $\%$ & 0 & 2010; Pardo et al., 2017) \\
Liquid fraction of S/L Sep. & $\%$ & 85 & (Möller et al., 2010) \\
Solid fraction of S/L Sep. & $\%$ & 15 & (Melse and de Buisonje, 2015) \\
Screw press electricity use & $\mathrm{kWh} \mathrm{m}^{-3}$ & 0.5 & (Fleming and MacAlpine, 2003; Møller et \\
Composting labour use & $\mathrm{h} \mathrm{m}^{-3}$ & 0.175 & al., 2000) \\
Composting fuel use & $\mathrm{L} \mathrm{m}^{-3}$ & 1.73 & (Anonymous, 1996) \\
Storage agitation electricity use & $\mathrm{kWh} \mathrm{m}^{-3}$ & 0.25 & (Anonymous, 1996) \\
\hline
\end{tabular}

$\operatorname{MNRE}(\%)=Q_{\text {nutrients recycled }} / I_{\text {nutrients excretion }} \times 100$ 
$N P V=-I+\sum_{t=0}^{n} C F_{t} /(1+r)^{t}$

194 where,

$195 \mathrm{NPV}=$ Net present value

196 I = Initial capital investment cost

$197 \mathrm{CF}=$ Expected cash flow at time $\mathrm{t}$

$198 r=$ Discount factor

$0=P_{0}+P_{1} /(1+I R R)+P_{2} /(1+I R R)^{2}+\cdots+P_{n} /(1+I R R)^{n}$

199 where,

$200 \mathrm{P}_{0}, \mathrm{P}_{1}, \ldots \mathrm{P}_{\mathrm{n}}=$ Cash flows in periods $1,2, \ldots n$.

201 IRR= internal rate of return.

$B C R=G P / T P C$

202 where,

$203 \mathrm{GP}=$ Gross profit

$204 \quad$ TPC $=$ Total production cost

$P B P=T I C / G P$

205 where,

206 TIC $=$ Total investment cost

$\mathrm{PI}=\left(\mathrm{TR} /(1+\mathrm{r})^{\mathrm{n}}\right) / T I C$

207 where,

$208 \mathrm{TR}=$ Total revenue

$209 n=$ number of years for which the cash flows is calculated

Table S17. Parameters and coefficients for financial analysis

Maintenance

$\begin{array}{lll}\text { (a) building and constructions } & \% & 3 \\ \text { (b) equipment } & \% & 5\end{array}$ 
Separation using sand bedding

$$
\%
$$$$
\mathrm{y}
$$

Duration of investment

Salvage rate

$\%$ of initial cost

Life span

(a) building and constructions

y

$\mathrm{y}$

20

(b) equipment

Pre-production costs

Contingencies

Administrative costs

Insurance cost

Tax rate

Annual discount rate

Loan rate

Interest rate on loan

Loan repayment period

Loan type

\subsection{Description of the case and scenarios}

Table S18. Characteristics of the studied farm

\begin{tabular}{lclc}
\hline Breed & Holstein & No. of cattle & 9062 \\
Actual capacity & 4500 heads & Milk yield (daily) & $42 \mathrm{~kg} \mathrm{head}^{-1}$ \\
(Lactating) & $3.2 \%$ & Milk protein & $2.7 \%$ \\
Milk fat & $680 \mathrm{~kg} \mathrm{head}^{-1}$ & LW-heifer & $515 \mathrm{~kg} \mathrm{head}^{-1}$ \\
LW-Lactating and dry & $2.08 \mathrm{y}$ & Fertility rate & 0.95 \\
Age at first calving & $22.16^{\circ} \mathrm{C}$ & Avg. temperature- winter & $7.5{ }^{\circ} \mathrm{C}$ \\
Avg. temperature- summer & Freestall/ Loose & Floor type & covered \\
Housing & Sand/organic material & Collection method & Vacuum machine/blade \\
Bedding & $20 \mathrm{~m}^{3}$ & Transportation & and loader \\
Collection capacity & $20 \mathrm{~m}^{3}$ & Diesel fuel consumption & Truck \\
Transport capacity & $1 \mathrm{~km}^{-1}$ & Avg. distance to land & $0.16 \mathrm{~L} \mathrm{~m}^{-1}$ \\
Distance to collection site & Pit without cover & Solid storage & $30 \mathrm{~km}^{\circ}$ \\
Liquid storage & $90 \times 10 \times 1.7 \mathrm{~m}$ & Avg. dimension of heap & Heap without cover \\
Avg. dimension of pit & & & $12 \times 4 \times 6 \mathrm{~m}$ \\
\hline 1
\end{tabular}


Table S19. Current market prices of manure products

\begin{tabular}{lcc}
\hline Market prices & Unit & $€^{1}$ \\
\hline Solid fertilizer & $€ \mathrm{~kg}^{-1}$ & 0.03 \\
Liquid fertilizer & $€ \mathrm{~kg}^{-1}$ & 0.003 \\
Bio-electricity & $€ \mathrm{kWh}^{-1}$ & 0.09 \\
Heat & $€ \mathrm{kWh}^{-1}$ & 0.004 \\
Compost & $€ \mathrm{~kg}^{-1}$ & 0.02 \\
Solid manure & $€ \mathrm{~kg}^{-1}$ & 0.02 \\
${ }^{1}$ Euro & &
\end{tabular}

213

\subsection{Sensitivity analysis}

Sensitivity analyses (SA) were performed for future scenarios and their impact to different indicators regarding the condition change in SA. The SA modeling details are described below:

\subsubsection{Passive windrow composting instead of intensive windrow composting}

In this sensitivity analysis, the alternative method for composting was considered to be passive windrow composting. This method of composting involves decomposing of material over a long time with no or little agitation of animal manure. Therefore, it consumes less labour and equipment. Although the composting process is slow, it may have less environmental burdens and greater potential for odour reduction (at the expense of anaerobic composting). The results were calculated for scenarios including composting treatment (Sc. 3, 5 and 7 based on Table 1). The alternative coefficients and emission factors are presented in Tables S12 and S13.

\subsubsection{Storage of manure in heaps and pits with cover instead of storage without cover}

In this sensitivity analysis a covered storage of manure in pits and heaps was assumed. Storage of liquid manure in pit without cover and solid manure in pyramidal heaps with rectangular basis less than $2 \mathrm{~m}$ height and $4 \mathrm{~m}$ width was considered. A cover (or crust) 
creates aerobic conditions on the surface and reduces $\mathrm{CH}_{4}$ and $\mathrm{NH}_{3}$ emissions but may increase $\mathrm{N}_{2} \mathrm{O}$ emissions (Rotz et al., 2016). Total GHG emissions are higher without this cover. The relevant coefficients and emission factors are presented in Table S14.

\subsubsection{Impact of changing some input parameters}

In this type of sensitivity analysis, four major influencing parameters were changed by $+10 \%$. These parameters included DM, leakage from biogas installations, electricity price and interest rate and their effects on GWP, nutrients recovery and NPV indicators were analysed and described. To select parameters with strong impact on the results by more than $\pm 1 \%$, a cut-off criterion was adopted.

The nutrients content and GWP were calculated proportionally to DM content changes. In this study, the sensitivity scenarios of the higher and lower DM content were compared with their corresponding treatment scenarios.

However, the impact of greater than $1 \%$ leakage may not be so realistic in large scale AD plants, the change of this parameter was analysed and the impacts on GWP and avoided emissions were estimated.

The sensitivity of NPV affected by changing electricity price and interest rate by $\pm 10 \%$, were discovered. The price of electricity from CHP is a tariff set by the Ministry of Power in Iran (70\% loan on green energy projects). The results of this sensitivity analysis may be helpful for policy makers to see the effect of changing electricity tariffs on biogas projects from the farmers' perspective.

\section{Results}

\subsection{Mass balance of nutrients}


Table S20. Estimated dairy manure properties and characteristics

\begin{tabular}{lcccc}
\hline \multirow{2}{*}{ Properties } & \multicolumn{3}{c}{ Cow subcategories $\left(\mathrm{kg} \mathrm{animal}^{-1} \mathrm{~d}^{-1}\right)$} & \multirow{2}{*}{ Total amount $\left(\mathrm{kg} \mathrm{d}^{-1}\right)$} \\
& Lactating cows & Dry cows & Heifers & \\
\hline N intake via feed & 0.64 & 0.17 & 0.22 & $3,963.22$ \\
N retention milk and growth & 0.21 & 0.00 & 0.01 & $1,041.46$ \\
N excretion & 0.43 & 0.17 & 0.21 & $2,931.06$ \\
P intake via feed & 0.08 & 0.02 & 0.02 & 456.57 \\
P retention milk and growth & 0.04 & 0.00 & 0.00 & 216.60 \\
P excretion & 0.04 & 0.02 & 0.02 & 239.97 \\
K intake via feed & 0.29 & 0.11 & 0.18 & $2,132.10$ \\
K retention milk and growth & 0.07 & 0.00 & 0.00 & 319.61 \\
K excretion & 0.23 & 0.11 & 0.18 & $1,812.50$ \\
VS & 6.57 & 1.86 & 2.56 & $41,795.66$ \\
VS & 2.74 & 0.77 & 1.07 & $17,414.86$ \\
VS & 3.83 & 1.08 & 1.49 & $24,380.80$ \\
C excretion & 3.81 & 1.08 & 1.49 & $24,241.48$ \\
TS & 9.66 & 2.66 & 3.53 & $60,548.80$ \\
TME & 80.48 & 22.19 & 29.40 & $504,573.35$ \\
TAN fraction & 0.62 & 0.74 & 0.73 & 0.70 \\
C:N ratio & 8.79 & 6.47 & 7.13 & 7.46 \\
\hline
\end{tabular}




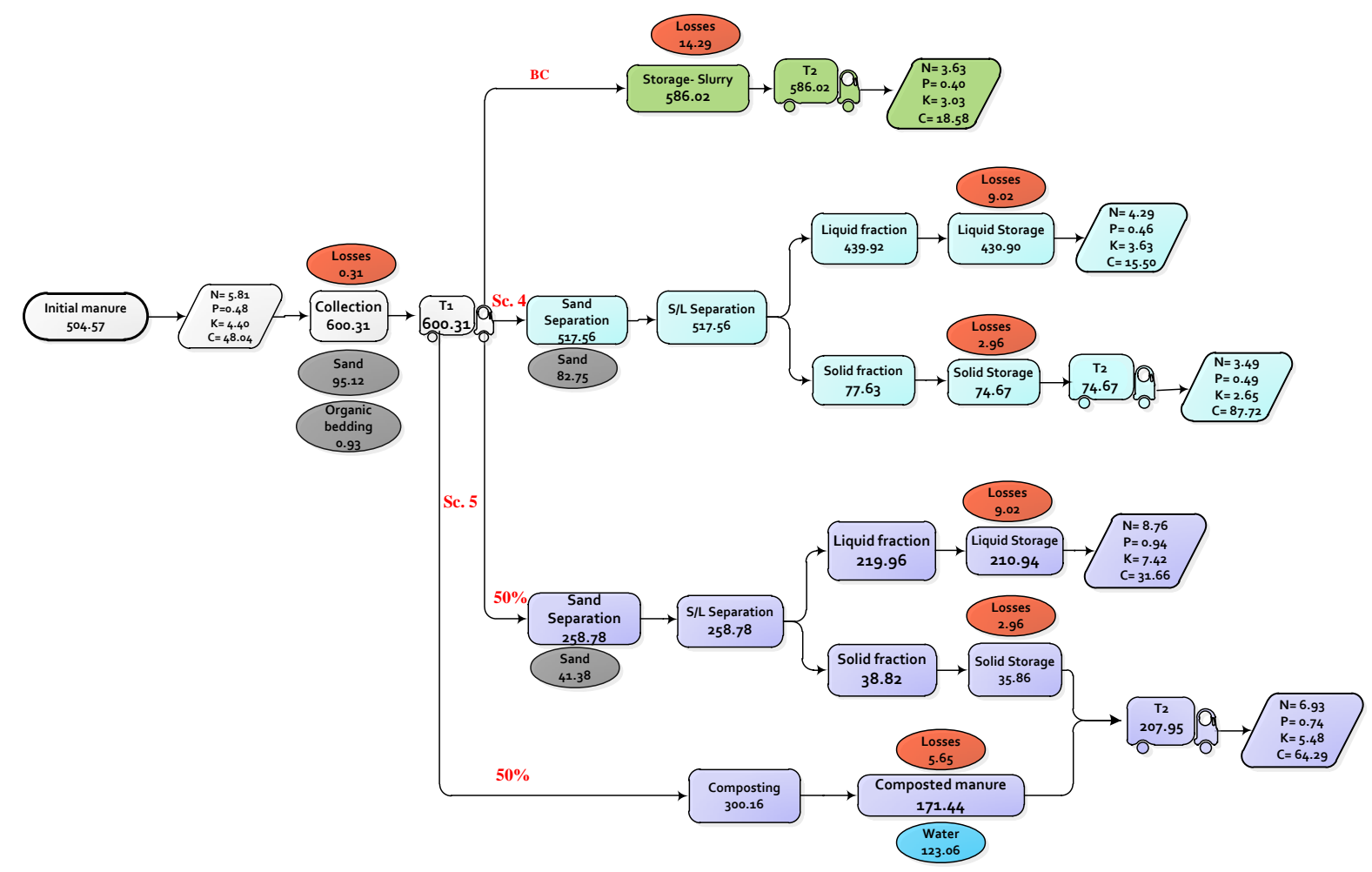

Fig. S2. Mass balance through Sc. 1, Sc. 4 and Sc. 5 (the unit for all values are $\mathrm{t} \mathrm{d}^{-1}$ except for values in trapezoids are $\mathrm{kg} \mathrm{t}^{-1}$ ).



Fig. S3. Mass balance through Sc. 6, Sc. 7 and Sc. 8 (the unit for all values are $\mathrm{t} \mathrm{d}^{-1}$ except for values in trapezoids are $\mathrm{kg} \mathrm{t}^{-1}$ ).

3.2. Sensitivity analysis results 

changes are presented in Figs. S4-S7. As expected, storing manure in covered area caused reducing emissions for all scenarios. The difference between covered and uncovered storages in terms of environmental impacts is depicted in Fig. S4. more sensitive in Sc. 7 and 8 where composting was carried out. Nitrogen and phosphorus showed less sensitivity to DM change. It was showed that DM content had impact on environmental outcomes and nutrient contents by Prapaspongsa et al. (2010).

This sensitivity analysis emphasized the importance of leakage losses in environmental performance of biogas production. This is further detailed in the SI (Fig. S6). As expected, greater (smaller) leakage rate $\left( \pm 10 \%\right.$ ) led to more (less) $\mathrm{CH}_{4}$ losses and GWP impact as opposed to $1 \%$ in its corresponding initial scenario and resulted in less emissions captured 271 during AD process.

The impact of electricity price, loans on renewable energy projects and interest rates were examined (Fig. S7). A 10\% change in the $\mathrm{r}$ would have the biggest influence on NPV of the projects, with greater impact on Sc. 8. NPV is negatively related to the annual discount rate (r) which indicates an increase in $r$ caused to NPV reduction. NPV is sensitive to the loan rate and electricity price. NPV is more influential in scenarios that involved all manure $(100 \%$ of 277 digestate) passing through the solid/liquid separation, than scenario 6 with $50 \%$ composting. This is due to the efficiency of S/L Sep. in separating slurry into solid fraction. 


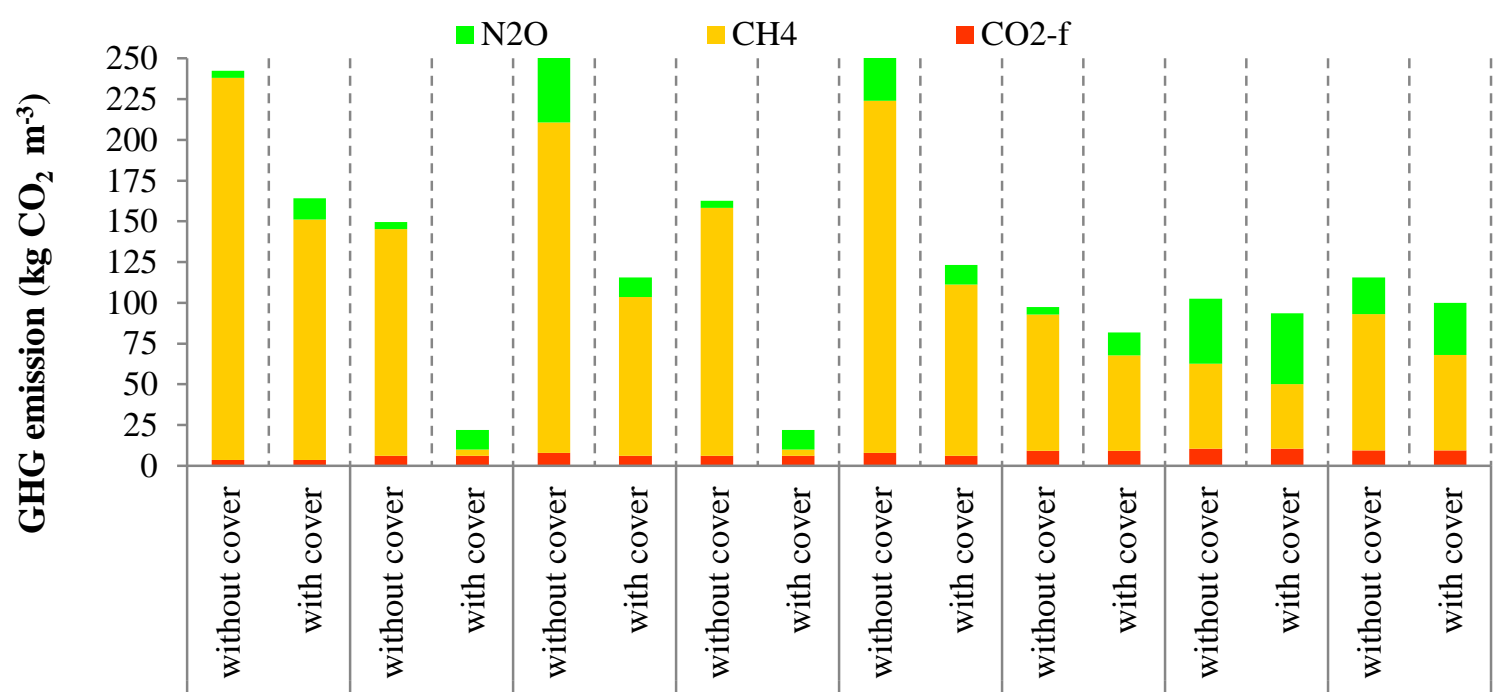

Fig. S4. Breakdown of the covered storage impact for the GHG emissions

(a)

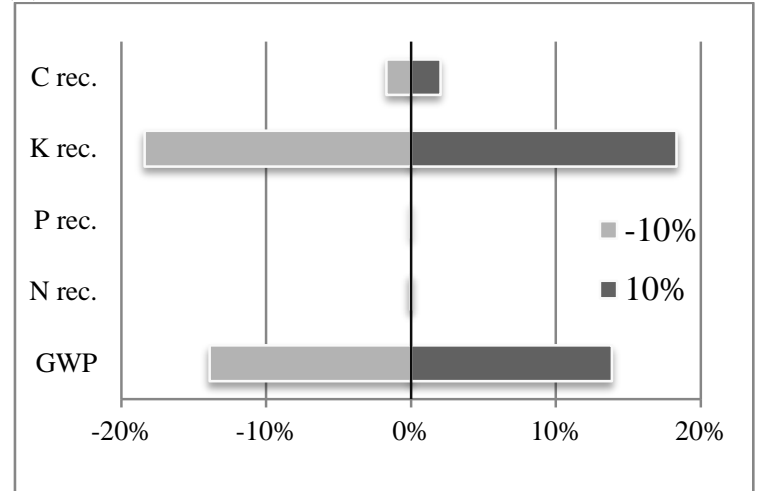

(b)

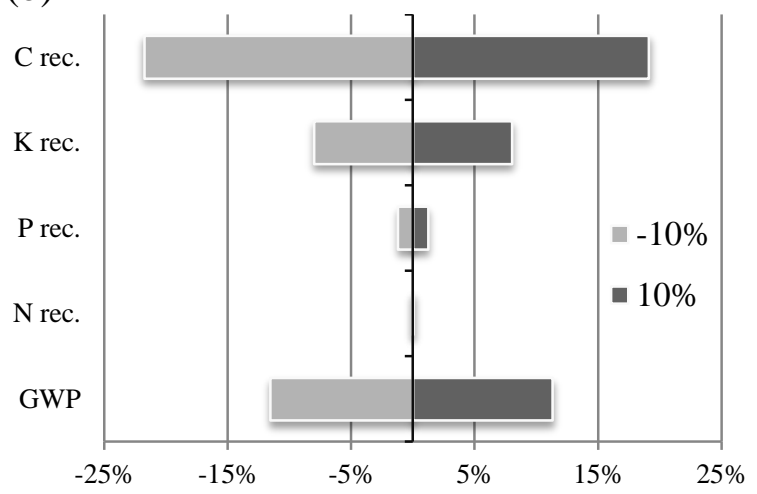

(c)

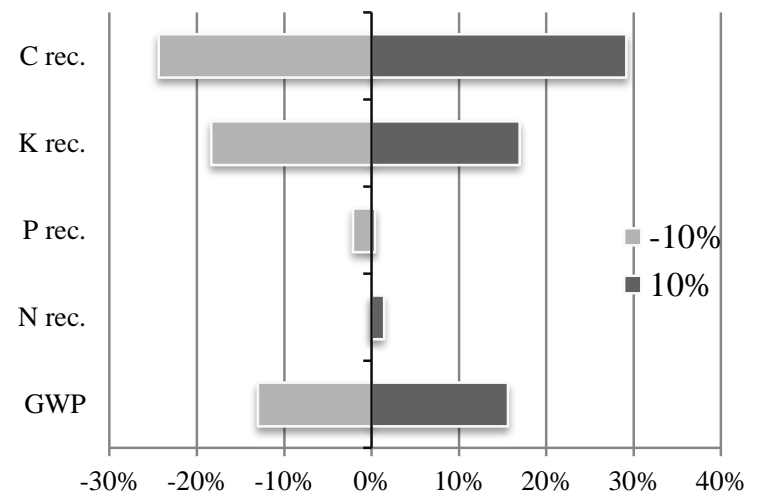

Fig. S5. Changes in GWP, N, P, K and C recovery for a $\pm 10 \%$ change of parameters for a) scenario 6 b) scenario 7 and c) scenario 8 . 


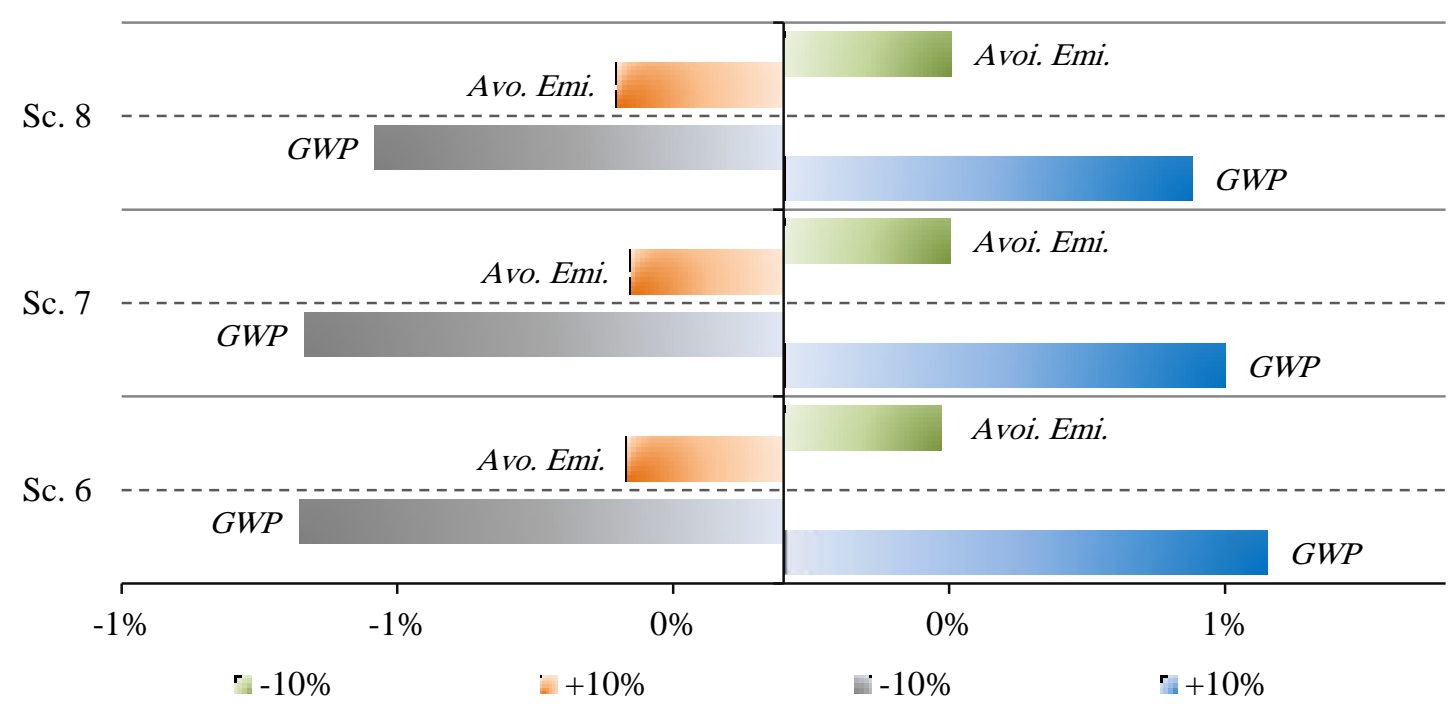

Fig. S6. Changes in GWP and avoided emissions (Avo. Emi) for a $\pm 10 \%$ change of leakage for Scs. 6-8.

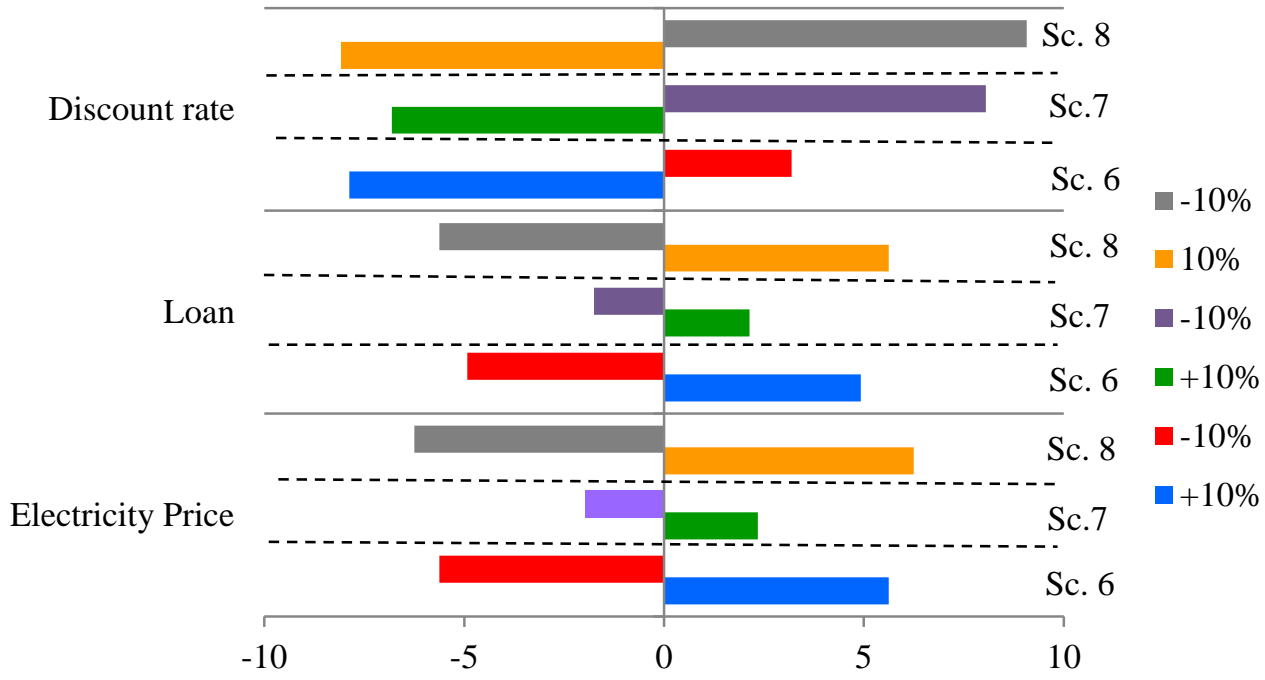

Fig. S7. Changes in NPV for a $\pm 10 \%$ change of electricity price, loan and discount rate for Scs. 6-8.

\section{References}

3.3, E., 2016. Ecoinvent ${ }^{\circledR S}$ Swiss Center for Life Cycle Inventories. 286 http://www.ecoinvent.org/database/ecoinvent-33/ecoinvent-33.html. (Accessed 06 June 287 2018).

288 Aguirre-Villegas, H.A., Larson, R., Reinemann, D.J., 2014. From waste-to-worth: energy, 289 emissions, and nutrient implications of manure processing pathways. Biofuels, Bioproducts and Biorefining 8(6), 770-793. 
Amon, B., Kryvoruchko, V., Amon, T., Zechmeister-Boltenstern, S., 2006. Methane, nitrous oxide and ammonia emissions during storage and after application of dairy cattle slurry and influence of slurry treatment. Agriculture, Ecosystems \& Environment 112(2-3), 153-162.

Anonymous, 2011. Statistical Report for Electricity Generation. Iran Power Generation, Transmission \& Distribution Management Company. Ministry of Energy (In Persian).

Anonymous, 2017. Energy density. https://en.wikipedia.org/wiki/Energy_density. (Accessed 06 June 2018).

Anonymous, 1996. Windrow composting systems can be feasible, cost effective. https://www.cias.wisc.edu/windrow-composting-systems-can-be-feasable-cost-effective/.

300 (Accessed 06 June 2018).

Anonymous, C.H.a.P.P.C., Catalog of CHP technologies, 2013. Combined Heat and Power Partnership (CHP), Catalog of CHP technologies. https://www.epa.gov/sites/production/files/2017-09/documents/catalog-of-chp-technologiessection-7.pdf. (Accessed 06 June 2018).

Bachmann, S., Wentzel, S., Eichler-Löbermann, B., 2011. Codigested dairy slurry as a phosphorus and nitrogen source for Zea mays L. and Amaranthus cruentus L. Journal of Plant Nutrition and Soil Science 174(6), 908-915.

Beline, F., Martinez, J., Marol, C., Guiraud, G., 1998. Nitrogen transformations during anaerobically stored 15N-labelled pig slurry. Bioresource Technology 64(2), 83-88.

Bianchi, S.R., Miyazawa, M., Oliveira, E.L.d., Pavan, M.A., 2008. Relationship between the 51(2), 263-269.

Chadwick, D., 2005. Emissions of ammonia, nitrous oxide and methane from cattle manure heaps: effect of compaction and covering. Atmospheric Environment 39(4), 787-799.

Chianese, D., Rotz, C., Richard, T., 2009. Simulation of carbon dioxide emissions from dairy farms to assess greenhouse gas reduction strategies. Transactions of the ASABE 52(4), 13011312.

Clemens, J., Trimborn, M., Weiland, P., Amon, B., 2006. Mitigation of greenhouse gas emissions by anaerobic digestion of cattle slurry. Agriculture, Ecosystems \& Environment 112(2-3), 171-177.

Daneshi, A., Esmaili-Sari, A., Daneshi, M., Baumann, H., 2014. Greenhouse gas emissions of packaged fluid milk production in Tehran. Journal of Cleaner Production 80, 150-158.

De Vries, J., Vinken, T., Hamelin, L., De Boer, I., 2012. Comparing environmental consequences of anaerobic mono-and co-digestion of pig manure to produce bio-energy-a life cycle perspective. Bioresource Technology 125, 239-248.

Eghball, B., Power, J.F., Gilley, J.E., Doran, J.W., 1997. Nutrient, carbon, and mass loss during composting of beef cattle feedlot manure. Journal of Environmental Quality 26(1), 189-193. 
Feedipedia, 2017. Animal Feed Resources Information System. http://www.feedipedia.org. (Accessed 06 June 2018).

Fleming, R., MacAlpine, M., 2003. Evaluation of mechanical liquid/solid manure separators. http://www.ridgetownc.uoguelph.ca/research/documents/fleming_Separatortesting.pdf.

333 (Accessed 06 June 2018).

FNR, 2006. Handreichung Biogasgewinnung und - Nutzung. - 3. überarbeitete Auflage; Fachagentur Nachwachsende Rohstoffe (In German). https://www.bigeast.eu/downloads/FNR_HR_Biogas.pdf. (Accessed 06 June 2018).

337 Frey, J., Grüssing, F., Nägele, H., Oechsner, H., 2013. Cutting the electric power consumption of biogas plants: the impact of new technologies. Landtechnik 68(1), 58-63.

Gibbs, P., Parkinson, R., Misselbrook, T., Burchett, S., 2002. Environmental impacts of cattle manure composting, Microbiology of Composting. Springer, pp. 445-456.

Gooch, C., Wedel, A., Karszes, J., 2003. Economic analysis of mechanical sand-manure separation of flushed sand-laden dairy manure, 2003 ASAE Annual Meeting. American Society of Agricultural and Biological Engineers.

Grisso, R.D., Kocher, M.F., Vaughan, D.H., 2004. Predicting Tractor Fuel Consumption.

Hamelin, L., Naroznova, I., Wenzel, H., 2014. Environmental consequences of different carbon alternatives for increased manure-based biogas. Applied Energy 114, 774-782.

Hill, D., 1984. Methane productivity of the major animal waste types. Transactions of the ASAE 27(2), 530-0534.

Hou, Y., 2016. Towards improving the manure management chain. Wageningen University.

IPCC, 2006. Agriculture, forestry and other land use, Guidelines for National Greenhouse (Accessed 06 June 2018).

Jørgensen, P.J., 2009. Biogas- green energy, Process, Design, Energy supply, Environment, 2 ed. Faculty of Agricultural Sciences, Aarhus University, Danmark.

Lansche, J., Müller, J., 2012. Life cycle assessment of energy generation of biogas fed Engineering in Life Sciences 12(3), 313-320. 
Melse, R., de Buisonje, F., 2015. Quick calculation tool for manure separation and distribution of mass, minerals and dry matter. http://sdddc.org/en/download/detail-155.aspx. (Accessed 06 June 2018).

Menind, A., Olt, J., 2009. Biogas plant investment analysis, cost benefit and main factors. Malinovska, L., Meote, A., kronbergs, e., Nulle, i.(editors), Engineering for Rural Development, 28-29.

Michel Jr, F.C., Pecchia, J.A., Rigot, J., Keener, H.M., 2004. Mass and nutrient losses during the composting of dairy manure amended with sawdust or straw. Compost Science \& Utilization 12(4), 323-334.

Misselbrook, T.H., Gilhespy, S., Cardenas, L.M., Williams, J., U., D., 2015. Inventory of Ammonia Emissions from UK Agriculture, Inventory Submission Report. London, UK.

Møller, H.B., Lund, I., Sommer, S.G., 2000. Solid-liquid separation of livestock slurry: efficiency and cost. Bioresource Technology 74(3), 223-229.

Møller, H.B., Sommer, S.G., Ahring, B.K., 2004. Methane productivity of manure, straw and solid fractions of manure. Biomass and Bioenergy 26(5), 485-495.

Möller, K., Schulz, R., Müller, T., 2010. Substrate inputs, nutrient flows and nitrogen loss of two centralized biogas plants in southern Germany. Nutrient Cycling in Agroecosystems 87(2), 307-325.

Möller, K., Stinner, W., 2010. Effects of organic wastes digestion for biogas production on mineral nutrient availability of biogas effluents. Nutrient Cycling in Agroecosystems 87(3), 395-413.

Nayyeri, M., Kianmehr, M., Arabhosseini, A., Hassan-Beygi, S., 2009. Thermal properties of dairy cattle manure. International Agrophysics 23(4), 359-366.

NRC, 2001. Nutrient requirements of dairy cattle, 7 ed. National Academies Press, Natl. Acad. Press, Washington, DC.

Pardo, G., Moral, R., del Prado, A., 2017. SIMSWASTE-AD-A modelling framework for the environmental assessment of agricultural waste management strategies: Anaerobic digestion. Science of the Total Environment 574, 806-817.

Parkinson, R., Gibbs, P., Burchett, S., Misselbrook, T., 2004. Effect of turning regime and seasonal weather conditions on nitrogen and phosphorus losses during aerobic composting of cattle manure. Bioresource Technology 91(2), 171-178.

Petersen, S.O., Lind, A.-M., Sommer, S.G., 1998. Nitrogen and organic matter losses during storage of cattle and pig manure. The Journal of Agricultural Science 130(1), 69-79.

Prapaspongsa, T., Christensen, P., Schmidt, J.H., Thrane, M., 2010. LCA of comprehensive pig manure management incorporating integrated technology systems. Journal of Cleaner Production 18(14), 1413-1422.

Rotz, C., 2004. Management to reduce nitrogen losses in animal production 1. Journal of Animal Science 82(13_suppl), E119-E137. 
Rotz, C.A., Corson, M.S., Chianese, D.S., Montes, F., Hafner, S.D., Bonifacio, H.F., Coiner,

403 C.U., 2016. Integrated Farm System Model: Reference Manual. Vol. 4.3. Pasture Systems and Watershed Management Research Unit, Agricultural Research Service, USDA, United States.

406 Schils, R., De Haan, M., Hemmer, J., Van den Pol-van Dasselaar, A., De Boer, J., Evers, A., 407 Holshof, G., Van Middelkoop, J., Zom, R., 2007. DairyWise, a whole-farm dairy model. 408 Journal of Dairy Science 90(11), 5334-5346.

Sommer, S.G., 2001. Effect of composting on nutrient loss and nitrogen availability of cattle deep litter. European Journal of Agronomy 14(2), 123-133.

Sommer, S.G., Petersen, S.O., Møller, H.B., 2004. Algorithms for calculating methane and nitrous oxide emissions from manure management. Nutrient Cycling in Agroecosystems 69(2), 143-154.

Ström, G., Albihn, A., Jinnerot, T., Boqvist, S., Andersson-Djurfeldt, A., Sokerya, S., Osbjer, K., San, S., Davun, H., Magnusson, U., 2018. Manure management and public health: Sanitary and socio-economic aspects among urban livestock-keepers in Cambodia. Science of the Total Environment 621, 193-200.

ten Hoeve, M., Hutchings, N.J., Peters, G.M., Svanström, M., Jensen, L.S., Bruun, S., 2014. Life cycle assessment of pig slurry treatment technologies for nutrient redistribution in Denmark. Journal of Environmental Management 132, 60-70.

Tittonell, P., Rufino, M.C., Janssen, B.H., Giller, K.E., 2010. Carbon and nutrient losses during manure storage under traditional and improved practices in smallholder crop-livestock systems - evidence from Kenya. Plant and Soil 328(1-2), 253-269.

424 Torquati, B., Venanzi, S., Ciani, A., Diotallevi, F., Tamburi, V., 2014. Environmental sustainability and economic benefits of dairy farm biogas energy production: A case study in Umbria. Sustainability 6(10), 6696-6713.

427 Vonk, J., Bannink, A., van Bruggen, C., Groenestein, C., Huijsmans, J., van der Kolk, J., 428 Luesink, H., Voshaar, S.O., Sluis, S., Velthof, G., 2016. Methodology for estimating 429 emissions from agriculture in the Netherlands. Wageningen University \& Research, 430 Wageningen, The Netherlands.

431 Wedel, A., 2012. Sand-manure separation, Got Manure? Liverpool, NY, USA.

432 WUM, 2009. Dierlijke mest en mineralen 1990-2008. CBS, IKC-Veehouderij, LAMI, LEI433 DLO, RIVM en SLM (In Dutch).

434 Yu, L., Wensel, P.C., Ma, J., Chen, S., 2014. Mathematical modeling in anaerobic digestion 435 (AD). Journal of Bioremediation and Biodegradation 5(S4), 1-12. 